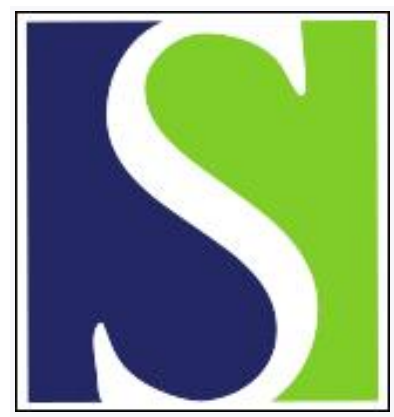

Scand J Work Environ Health 2019;45(3):217-238

https://doi.org/10.5271/sjweh.3800

Published online: 17 Jan 2019, Issue date: 01 May 2019

Current state of knowledge on the health effects of engineered nanomaterials in workers: a systematic review of human studies and epidemiological investigations

by Schulte PA, Leso V, Niang M, lavicoli I

This paper offers the reader a comprehensive and updated view of the possible health effects of individual types of engineered nanomaterials. It tracks epidemiological studies (and complimentary animal studies) of workers potentially exposed to nine of the highest volume engineered nanomaterials in commerce. Implications for biological monitoring were also extrapolated from the review.

Affiliation: National Institute for Occupational Safety and Health, Centers for Disease Control and Prevention, 1150 Tusculum Avenue, MS C-14, Cincinnati, OH 45226, USA. pas4@cdc.gov

Refers to the following text of the Journal: 2008;34(6):463-470

Key terms: animal investigation; biological monitoring; carbon nanotube; engineered nanomaterial; epidemiological investigation; epidemiological study; exposure; health effect; human health consequence; human study; nanomaterial; nanoparticle; nanoparticle impact; occupational exposure; occupational risk management workforce; review; systematic review

This article in PubMed: www.ncbi.nlm.nih.gov/pubmed/30653633

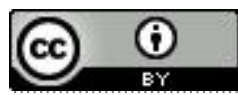




\title{
Current state of knowledge on the health effects of engineered nanomaterials in workers: a systematic review of human studies and epidemiological investigations
}

\author{
by Paul A Schulte, PhD, ${ }^{1}$ Veruscka Leso, MD, PhD, ${ }^{2}$ Mamadou Niang, MS, MPH, ${ }^{3}$ Ivo lavicoli, MD, PhD ${ }^{2}$
}

\begin{abstract}
Schulte PA, Leso V, Niang M, lavicoli I. Current state of knowledge on the health effects of engineered nanomaterials in workers: a systematic review of human studies and epidemiological investigations. Scand J Work Environ Health. 2019;45(3):217-238. doi:10.5271/sjweh.3800
\end{abstract}

Objectives The widespread application of nano-enabled products and the increasing likelihood for workplace exposures make understanding engineered nanomaterial (ENM) effects in exposed workers a public and occupational health priority. The aim of this study was to report on the current state of knowledge on possible adverse effects induced by ENM in humans to determine the toxicological profile of each type of ENM and potential biomarkers for early detection of such effects in workers.

Methods A systematic review of human studies and epidemiological investigations of exposed workers relative to the possible adverse effects for the most widely used ENM was performed through searches of major scientific databases including Web of Science, Scopus, and PubMed.

Results Twenty-seven studies were identified. Most of the epidemiological investigations were cross-sectional. The review found limited evidence of adverse effects in workers exposed to the most commonly used ENM. However, some biological alterations are suggestive for possible adverse impacts. The primary targets of some ENM exposures were the respiratory and cardiovascular systems. Changes in biomarker levels compared with controls were also observed; however, limited exposure data and the relatively short period since the first exposure may have influenced the incidence of adverse effects found in epidemiological studies.

Conclusions There is a need for longitudinal epidemiologic investigations with clear exposure characterizations for various ENM to discover potential adverse health effects and identify possible indicators of early biological alterations. In this state of uncertainty, precautionary controls for each ENM are warranted while further study of potential health effects continues.

Key terms animal investigation; biological monitoring; carbon nanotube; epidemiological study; exposure; human health consequence; nanoparticle; nanoparticle impact; occupational exposure; occupational risk management; workforce.

After almost 20 years of engineered nanomaterials (ENM) use in commerce, it is time to assess what is known about their health effects among workers. As the production of nanomaterials has grown, so has the workforce handling them. Within this growing workforce, the numbers of workers with adverse health effects from ENM exposure remains relatively unknown (1). The following factors can affect the assessment of ENM health effects: (i) the immense universe of potentially unique ENM and the great diversity in their toxic potential requires a unique assessment for each type, making a single overarching assessment of ENM health effects inappropriate; (ii) an assumed low extent of exposures due to a global attempt to promote responsible development of nanotechnology through preventive measures to control exposure to workers $(2,3)$; (iii) difficulty assembling study cohorts of similarly exposed workers due to decentralized manufacture and use of $\operatorname{ENM}(4,5)$; and (iv) a lack of clarity on appropriate early indicators or biomarkers of adverse health effects.

1 National Institute for Occupational Safety and Health, Centers for Disease Control and Prevention, Cincinnati, OH, USA.

2 Department of Public Health, University of Naples Federico II, Naples, Italy.

3 Department of Environmental Health, University of Cincinnati, Cincinnati, OH, USA.

Correspondence to: Paul A Schulte, National Institute for Occupational Safety and Health, Centers for Disease Control and Prevention, 1150 Tusculum Avenue, MS C-14, Cincinnati, OH 45226, USA. [E-mail: pas4@cdc.gov] 
A systematic review of the literature on the adverse effects of ENM in workers may be helpful in determining if effects exist and how deeply they have been investigated. Determination of the health effects and linkage to the exposure is a function of the extent to which workers have been exposed and the duration of their exposure. Since it is relatively early in the commercial history of ENM, the number of exposed workers, the extent of exposure, and the time since first exposure are generally small, leading to a low probability for adverse effects to have occurred, particularly chronic health effects. The ENM workforce is also widely dispersed and generally not very large in any involved workplace. Consequently, there have been few exposure assessment and epidemiological studies. Moreover, the heterogeneity of ENM in terms of physico-chemical variables is large. More precisely, the reactivity of tissues to ENM is highly dependent on particle morphology and surface features, related to their chemical growth histories (6).

The aim of this review was to identify health effects or early biological alterations that have occurred in the nanomaterial workforce. In the process, the review identifies the biomarkers related to such effects. Ultimately, the review seeks to identify knowledge gaps that require future investigation to help define strategies for suitable risk assessment and management processes.

\section{Methods}

The state of knowledge about the health impact of ENM in occupationally exposed populations was investigated through a systematic review of adverse effects reported in human studies and epidemiological investigations. Human case studies may provide preliminary information on possible adverse effects that have occurred in a single subject or a small group of subjects because of ordinary or accidental conditions of exposure. Epidemiologic investigations, on the other hand, are more useful and informative, as they can show possible relationships between ENM exposure and health effects.

Considering the multitude of ENM employed in workplace settings, and the early phase of knowledge concerning their possible adverse impact on human health, this review was primarily focused on the nine most widely used ENM identified in a recent WHO report and is based on the tonnes ( $t$ ) of nanomaterials produced annually and used worldwide (7). These ENM include carbon black (9.6 million t); synthetic amorphous silica (1.5 million $\mathrm{t}$ ); aluminum oxide (200 $000 \mathrm{t})$; barium titanate (15000 t); titanium dioxide (10 $000 \mathrm{t}$ ), cerium dioxide (10 $000 \mathrm{t})$; zinc oxide (8000 t); carbon nanotubes (CNT) and carbon nanofibers (CNF) (100-3000 t); and silver nanoparticles (NP) (20 t). "The term ENM refers to materials that have at least one dimension (height, width, length) that is smaller than 100 nanometers." (7, p6)

The systematic review followed the PRISMA (Preferred Reporting Items for Systematic Reviews and Meta-analyses) guidelines for the period 2003-2018 (8). The year 2003 was selected as the starting date because it predated authoritative warnings of potential hazards of nanomaterials, such as those made by The Royal Society and Royal Academy of Engineering (9). The search used general databases at the University of Cincinnati (www. libraries.uc.edu), including the Web of Science, Scopus (Elsevier), PubMed, Academic Search Complete, Summon, and ProQuest. The following terms were employed to search for studies: "epidemiological studies", "human studies", "nanomaterial", "nanoparticles", "nanotubes", "carbon black", "carbon nanotubes", "titanium dioxide", "silver nanoparticles", "cerium oxide", "zinc oxide", "aluminum oxide", "synthetic amorphous silica", and "barium titanate".

A selection criterion for epidemiological studies included the use of a non-exposed or comparison group in the study. From previous investigations $(10,11)$, it was expected there would only be a small number of epidemiological biomarker studies. Most of the extant epidemiological studies of nanomaterial workers met the inclusion criteria and were included in the review, although some methodological criticisms emerged from previous analyses of such investigations (10-12). The aim of this review was to consider the findings in terms of commonality or divergence (10) between studies, pointing out coherent links with supporting literature, involving both human and animal subjects. Based on the findings of human and epidemiological studies, the scientific literature was further searched for information on mechanisms identified in or inferred from the results.

\section{Results}

An electronic search of library databases yielded 109 unique references for human studies of which 27 were eligible to include in this review (figure 1). Of the 27 human studies, some studies involved more than one type of ENM and some used the same groups of workers. Table 1 describes principle findings from studies of nanomaterial workers, that is, workers exposed to contemporary ENM. The following sections will summarize results obtained in human case and epidemiologic studies by ENM category.

\section{Carbon black}

Carbon black is a generic term for a high volume commercial material of many different types of amorphous 


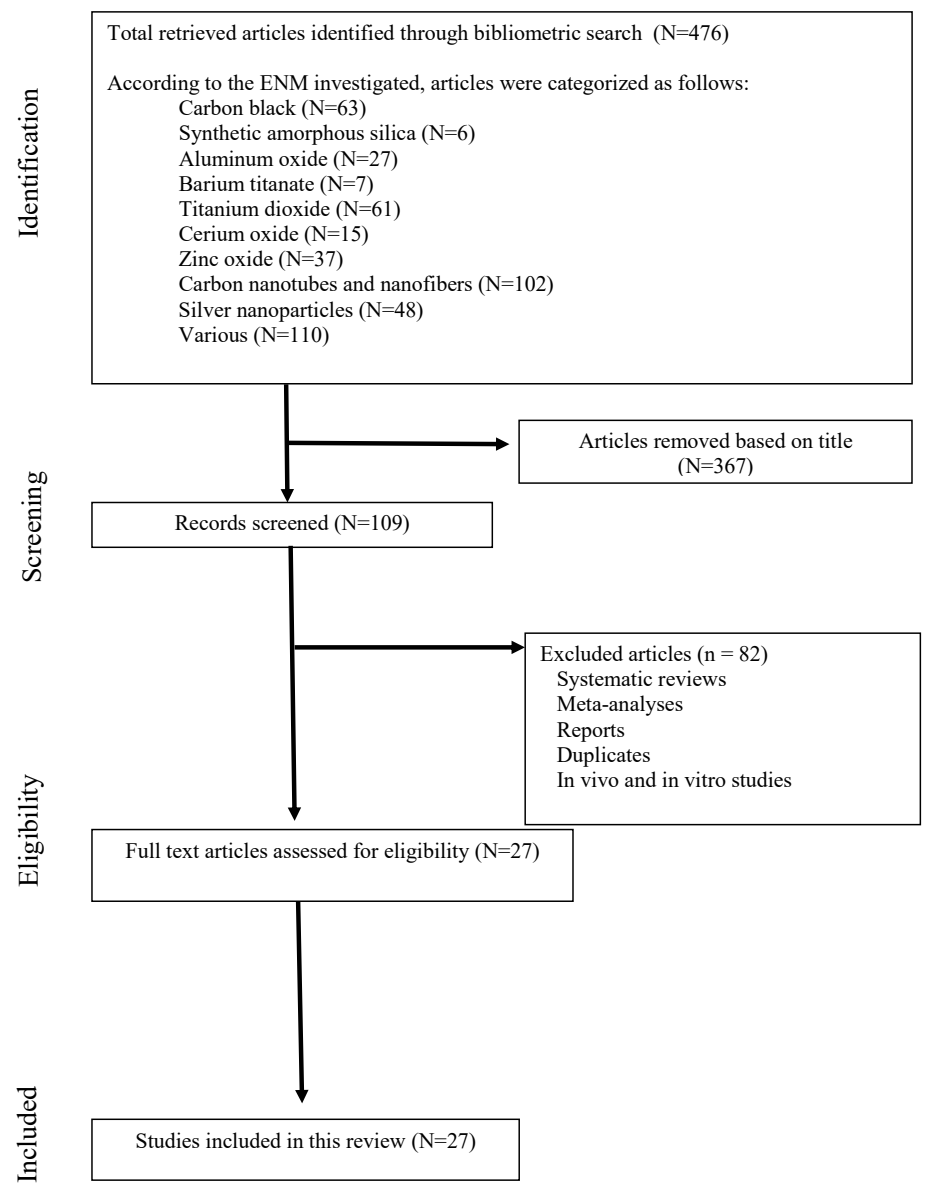

Figure 1. Flow chart for inclusion of epidemiologic and human case studies.

carbon with a wide range of particle sizes. Carbon black has been in commerce for over a century (13). Particle size may vary with use. Primary particles range from 1- $500 \mathrm{~nm}$; however, particles generally aggregate to sizes of 50-600 nm and, in turn, aggregates agglomerate to micron sizes (14). Carbon black particles of nanoscale size are manufactured by various vapor-phase processes, pyrolysis, and partial combustion or thermal decomposition of gaseous or liquid hydrocarbons (14). Non-malignant respiratory morbidity in terms of pulmonary function decrement and respiratory symptoms was seen in carbon black workers and was strongly correlated with the levels of exposure (15-19). The International Agency for Research on Cancer (IARC) deemed as inconsistent epidemiologic data of carbon black workers, which show some indications of lung cancer (14). The IARC did find a more consistent pattern of lung cancer in animal studies supported by mechanistic investigations (14) and concluded there was sufficient evidence in experimental animals for carcinogenicity. Consequently, carbon black was classified as a possible carcinogen to humans (14). However, the studies generally did not identify particle size. It cannot be excluded that some of the particles could be in the nanoscale range.

Although major concerns exist regarding the potential impact of human exposures to nano-sized carbon black particles, limited human data are currently available. In relation to clinical parameter alterations, in a cross sectional epidemiological study on carbon black workers, a significant reduction of lung functional parameters was evident compared to unexposed controls (20). This reduction of lung functional parameters included the percent predicted forced expiratory volume in 1 second (FEV1\%), FEV1/ forced vital capacity (FVC), percent predicted maximal mid-expiratory flow curve (MMF\%), and percent predicted peak expiratory flow $(\mathrm{PEF} \%)$. None of the exposed workers had pathologically low values of these parameters (20). The mean concentration of carbon black in this study, measured by personal samples was $14.90 \mathrm{mg} / \mathrm{m}^{3}$, which is 4.26 fold higher than the current TLV of $3.5 \mathrm{mg} / \mathrm{m}^{3}$ (20).

In a subsequent investigation, the same group of researchers analyzed possible changes exerted by carbon black ENM-occupational exposure on hematological indices (21). Their results showed a significant increase 
Table 1. Epidemiological and human case studies of nanomaterial workers. [NA=not available.]

\begin{tabular}{|c|c|c|c|c|}
\hline Nanomaterial a $^{a}$ & Reference & Particle size & $\begin{array}{l}\text { Workplace / } \\
\text { operations }\end{array}$ & $\begin{array}{l}\text { Sample size expose } \\
\text { non-exposed worke }\end{array}$ \\
\hline Carbon black & $\begin{array}{l}\text { Zhang et al } \\
(20)\end{array}$ & $\begin{array}{l}\text { Primary size: } \\
30-50 \mathrm{~nm}\end{array}$ & $\begin{array}{l}\text { Particle } \\
\text { production }\end{array}$ & $\begin{array}{l}\text { Exposed male work } \\
\text { ers }(\mathrm{N}=81) ; \text { non-ex- } \\
\text { posed male workers } \\
(\mathrm{N}=104)\end{array}$ \\
\hline Carbon black & $\begin{array}{l}\text { Dai et al } \\
(21)\end{array}$ & $\begin{array}{l}\text { Primary size: } \\
\text { 30-50 nm; } \\
\text { agglomerates: } \\
200-400 \mathrm{~nm}\end{array}$ & $\begin{array}{l}\text { Packing } \\
\text { pure carbon } \\
\text { black }\end{array}$ & $\begin{array}{l}\text { Exposed male work } \\
\text { ers }(\mathrm{N}=106) ; \text { non- } \\
\text { exposed controls } \\
(\mathrm{N}=112)\end{array}$ \\
\hline $\begin{array}{l}\text { Silica } \\
\text { nanoparticles }^{\text {b }}\end{array}$ & $\begin{array}{l}\text { Song et al } \\
\text { (34) }\end{array}$ & $30 \mathrm{~nm}$ & $\begin{array}{l}\text { Spray } \\
\text { painting }\end{array}$ & $\begin{array}{l}\text { Female workers in } \\
\text { spray painting for } \\
5-13 \text { months }(\mathrm{N}=8)\end{array}$ \\
\hline $\begin{array}{l}\text { Silica } \\
\text { nanoparticles }^{\text {b }}\end{array}$ & $\begin{array}{l}\text { Song et al } \\
\text { (35) }\end{array}$ & $\begin{array}{l}\text { Primary size: } \\
20-21 \mathrm{~nm}\end{array}$ & $\begin{array}{l}\text { Spray } \\
\text { painting }\end{array}$ & $\begin{array}{l}\text { Exposed workers } \\
\text { employed in spray } \\
\text { painting for } 5-13 \\
\text { months }(\mathrm{N}=8)\end{array}$ \\
\hline
\end{tabular}

\begin{tabular}{|c|c|c|c|c|c|}
\hline Titanium dioxide & $\begin{array}{l}\text { Ichihara } \\
\text { et al (68) }\end{array}$ & $\begin{array}{l}46-562 \mathrm{~nm} \\
<300 \mathrm{~nm}\end{array}$ & $\begin{array}{l}\text { Process and } \\
\text { handle }\end{array}$ & $\begin{array}{l}\text { Exposed workers } \\
(\mathrm{N}=16) \text {; no controls }\end{array}$ & $\begin{array}{l}\text { Handling }<300 \mathrm{~nm} \text { sized } \mathrm{TiO}_{2} \text {-ENM might affect heart rate variability in } \\
\text { workers. }\end{array}$ \\
\hline \multirow[t]{2}{*}{ Titanium dioxide } & \multirow[t]{2}{*}{$\begin{array}{l}\text { Pelclova } \\
\text { et al (69) }\end{array}$} & \multirow{2}{*}{$\begin{array}{l}80 \% \text { of } \\
\text { airborne } \\
\text { particles were } \\
<100 \mathrm{~nm}^{\mathrm{c}}\end{array}$} & \multirow{2}{*}{$\begin{array}{l}\text { Production } \\
\text { and } \\
\text { research }\end{array}$} & \multirow{2}{*}{$\begin{array}{l}\text { Exposed produc- } \\
\text { tion workers }(\mathrm{N}=32) \text {; } \\
\text { exposed research } \\
\text { workers }(\mathrm{N}=4) ; \text { non- } \\
\text { exposed controls } \\
(\mathrm{N}=45)\end{array}$} & $\begin{array}{l}\text { The concentration of titanium in } \mathrm{EBC} \text { may serve as a direct exposure } \\
\text { marker in workers producing } \mathrm{TiO}_{2} \text {. }\end{array}$ \\
\hline & & & & & $\begin{array}{l}\text { The markers of oxidative damage of nucleic acids and proteins in the } \\
\text { EBC were significantly higher in the more exposed production workers, } \\
\text { than in the research workers and unexposed controls. }\end{array}$ \\
\hline \multirow[t]{2}{*}{ Titanium dioxide } & \multirow[t]{2}{*}{$\begin{array}{l}\text { Pelclova } \\
\text { et al (67) }\end{array}$} & \multirow[t]{2}{*}{$\begin{array}{l}80 \% \text { of } \\
\text { particles } \\
<100 \mathrm{~nm}^{\mathrm{c}}\end{array}$} & \multirow[t]{2}{*}{$\begin{array}{l}\text { Manu- } \\
\text { facturing }\end{array}$} & \multirow{2}{*}{$\begin{array}{l}\text { Workers exposed to } \\
\mathrm{TiO}_{2}(\mathrm{~N}=30) ; \text { office } \\
\text { employees }(\mathrm{N}=22) ; \\
\text { non-exposed con- } \\
\text { trols }(\mathrm{N}=45)\end{array}$} & $\begin{array}{l}\text { Leukotrienes (LT) B4, C4, E4, and D4 were all elevated in the EBC samples } \\
\text { of exposed workers compared to controls and were directly correlated } \\
\text { with Ti concentrations. }\end{array}$ \\
\hline & & & & & $\begin{array}{l}\text { Office workers had higher LTB4 in EBC and higher levels of the fractional } \\
\text { exhaled nitric oxide. }\end{array}$ \\
\hline \multirow[t]{2}{*}{ Titanium dioxide } & \multirow[t]{2}{*}{$\begin{array}{l}\text { Pelclova } \\
\text { et al (70) }\end{array}$} & \multirow[t]{2}{*}{$\begin{array}{l}80 \% \text { of } \\
\text { particles } \\
<100 \mathrm{~nm}^{\mathrm{c}}\end{array}$} & \multirow[t]{2}{*}{$\begin{array}{l}\text { Manu- } \\
\text { facturing }\end{array}$} & \multirow[t]{2}{*}{$\begin{array}{l}\text { Exposed workers } \\
(\mathrm{N}=34) ; \text { non-exposed } \\
\text { controls }(\mathrm{N}=45)\end{array}$} & $\begin{array}{l}\text { All } 11 \text { markers of lipid oxidation analyzed were elevated in production } \\
\text { workers relative to the controls. } \mathrm{A} \text { dose-dependent association was } \\
\text { detected between exposure to } \mathrm{TiO}_{2} \text { and markers of lipid oxidation in the } \\
\text { EBC. }\end{array}$ \\
\hline & & & & & No elevation was evident in the urine samples. \\
\hline \multirow[t]{2}{*}{ Titanium dioxide } & \multirow[t]{2}{*}{$\begin{array}{l}\text { Pelclova } \\
\text { et al (71) }\end{array}$} & \multirow[t]{2}{*}{$\begin{array}{l}80 \% \text { of } \\
\text { particles } \\
<100 \mathrm{~nm}^{\mathrm{c}}\end{array}$} & \multirow[t]{2}{*}{$\begin{array}{l}\text { Manu- } \\
\text { facturing }\end{array}$} & \multirow[t]{2}{*}{$\begin{array}{l}\text { Exposed workers } \\
(\mathrm{N}=22) ; \text { non-exposed } \\
\text { controls }(\mathrm{N}=14)\end{array}$} & $\begin{array}{l}\text { Nine markers of lipid oxidation were elevated in the EBC of office employ- } \\
\text { ees relative to controls; only } 8 \text { isoprostane and aldehyde C12 were not } \\
\text { increased. }\end{array}$ \\
\hline & & & & & $\begin{array}{l}\text { Urine concentrations of the oxidative stress markers were not elevated } \\
\text { relative to the control group. }\end{array}$ \\
\hline \multirow[t]{2}{*}{ Titanium dioxide } & \multirow[t]{2}{*}{$\begin{array}{l}\text { Pelclova } \\
\text { et al (64) }\end{array}$} & \multirow{2}{*}{$\begin{array}{l}70-82 \% \text { of } \\
\text { airborne } \\
\text { particles } \\
\text { were }<100 \mathrm{~nm}\end{array}$} & \multirow{5}{*}{$\begin{array}{l}\text { Production } \\
\text { and } \\
\text { research }\end{array}$} & \multirow{2}{*}{$\begin{array}{l}\text { Production workers- } \\
\text { high risk of exposure } \\
(\mathrm{N}=16) \text {; research } \\
\text { Workers- medium } \\
\text { risk of exposure } \\
(\mathrm{N}=4) ; \text { non-exposed } \\
\text { controls }(\mathrm{N}=20)\end{array}$} & $\begin{array}{l}\text { Particles of rutile and/or anatase were found in the EBC of exposed } \\
\text { workers in } 8 / 20(40 \%) \text { of the pre-shift and 14/20 (70\%) of the post-shift } \\
\text { samples. }\end{array}$ \\
\hline & & & & & $\begin{array}{l}\text { The mean concentration of titanium in the EBC samples in produc- } \\
\text { tion workers was } 24.1 \pm 1.8 \mu \mathrm{g} \text { in the pre-shift and } 24.1 \pm 1.9 \mu \mathrm{g} \text { in } \\
\text { the post-shift, while in controls mean concentration was } \leq \text { the limit of } \\
\text { determination. }\end{array}$ \\
\hline \multirow[t]{3}{*}{ Titanium dioxide } & \multirow[t]{3}{*}{$\begin{array}{l}\text { Zhao et al } \\
\text { (65) }\end{array}$} & \multirow[t]{3}{*}{$\begin{array}{l}39 \% \text { of particles } \\
<100 \mathrm{~nm}\end{array}$} & & \multirow{3}{*}{$\begin{array}{l}\text { Exposed workers } \\
(\mathrm{N}=83) ; \text { non-exposed } \\
\text { controls }(\mathrm{N}=85)\end{array}$} & $\begin{array}{l}\text { Lung damage biomarkers: serum surfactant protein-D was significantly } \\
\text { lower in exposed workers compared to unexposed controls. }\end{array}$ \\
\hline & & & & & $\begin{array}{l}\text { Cardiovascular disease biomarkers: vascular cell adhesion protein 1, } \\
\text { (VCAM-1), intercellular adhesion molecule } 1 \text { (ICAM-1), and low density } \\
\text { lipoprotein were higher, while total cholesterol was reduced in exposed } \\
\text { workers compared to unexposed controls. }\end{array}$ \\
\hline & & & & & $\begin{array}{l}\text { Inflammation and oxidative stress markers: superoxide dismutase } \\
\text { (decreased) and malondialdehyde (increased); inflammation markers: } \\
\text { interleukin (IL)-8, IL-6, IL- } 1 \beta \text {, TNF- } \alpha \text {, and IL- } 10 \text { were increased and sig- } \\
\text { nificantly associated with occupational exposure to nano- } \mathrm{TiO}_{2} \text {. }\end{array}$ \\
\hline \multirow{2}{*}{$\begin{array}{l}\text { Multi-walled } \\
\text { carbon } \\
\text { nanotubes }\end{array}$} & \multirow[t]{2}{*}{$\begin{array}{l}\text { Fatkhutdinova } \\
\text { et al (123) }\end{array}$} & \multirow{2}{*}{$\begin{array}{l}\text { External diam- } \\
\text { eter: } 8-15 \mathrm{~nm} \text {; } \\
\text { internal diam- } \\
\text { eter 4-8 } \mathrm{nm} \text {; } \\
\text { length: } \geq 2 \mu \mathrm{m}\end{array}$} & \multirow{2}{*}{$\begin{array}{l}\text { Nano- } \\
\text { material } \\
\text { manu- } \\
\text { facturing }\end{array}$} & \multirow{2}{*}{$\begin{array}{l}\text { Exposed workers } \\
(\mathrm{N}=10) ; \text { non-exposed } \\
\text { controls }(\mathrm{N}=12)\end{array}$} & $\begin{array}{l}\text { Inflammatory biomarkers (serum): IL-1 } 1 \beta \text {, IL-4, and TNF- } \alpha \text { were signifi- } \\
\text { cantly elevated in the MWCNT exposed group. }\end{array}$ \\
\hline & & & & & $\begin{array}{l}\text { Inflammatory biomarkers (sputum): profibrotic inflammatory biomarkers, } \\
\text { such as cytokines IL-1 } \beta \text {, IL-4, IL-5, IL-6, IL-8, TNF- } \beta \text { and KL- } 6 \text { were signifi- } \\
\text { cantly higher in exposed workers compared to unexposed controls. }\end{array}$ \\
\hline
\end{tabular}

No changes found in chest $x$-rays images.

Significant, although no pathological, reduction of lung functional parameters: FEV1\%, FEV1/FVC, MMF\%, and PEF\% in exposed workers compared to unexposed controls.

IL-1 $\beta$, IL-6, IL-8, MIP-1 $\beta$, and TNF- alpha had 2.86-, 6.85-, 1.49-, 3.35and 4.87 -folds increase in serum of carbon black workers compared to unexposed controls.

Peripheral blood eosinophil count in exposed workers increased by $30.8 \%$ compared to unexposed controls.

Seven female workers claimed shortness of breath, pleural and pericardial effusion, pulmonary inflammation (2 died)

In the early stages (within 3 months of disease onset), ENM 20-21 nm in diameter were observed and found in the cytoplasm, nuclei and organelles of macrophages, pulmonary microvessels, pulmonary vascular endothelial cells, and microlymphatic vessels.

In the late disease stage (18 months, just prior to death), few ENM were observed in pulmonary cells and interstitial tissue, as well a few in macrophages

Handling $<300 \mathrm{~nm}$ sized $\mathrm{TiO}_{2}$-ENM might affect heart rate variability in workers.

$80 \%$ of

marker in workers producing $\mathrm{TiO}_{2}$

The markers of oxidative damage of nucleic acids and proteins in the

EBC were significantly higher in the more exposed production workers

of exposed workers compared to controls and were directly correlated

with Ti concentrations.

Office workers had higher LTB4 in EBC and higher levels of the fractional exhaled nitric oxide.

workers relative to the controls. A dose-dependent association was

No elevation was evident in the urine samples

we retive increased.

workers in $8 / 20(40 \%)$ of the pre-shift and $14 / 20(70 \%)$ of the post-shift

airborne and high risk of exposure

Workers- medium isk of exposure

The mean concentration of titanium in the EBC samples in producdetermination.

Exposed workers Lung damage biomarkers: serum surfactant protein-D was significantly $(\mathrm{N}=83)$; non-exposed lower in exposed workers compared to unexposed controls.

Cardiovascular disease biomarkers: vascular cell adhesion protein 1 ( workers compared to unexposed controls. (decreased) and malondialdehyde (increased); inflammation markers: in nificantly associated with occupational exposure to nano- $\mathrm{TiO}_{2}$. 
Table 1. continued.

\begin{tabular}{|c|c|c|c|c|c|}
\hline Nanomaterial ${ }^{\mathrm{a}}$ & Reference & Particle size & $\begin{array}{l}\text { Workplace I } \\
\text { operations }\end{array}$ & $\begin{array}{l}\text { Sample size exposed/ } \\
\text { non-exposed workers }\end{array}$ & Findings \\
\hline $\begin{array}{l}\text { Multi-walled } \\
\text { carbon } \\
\text { nanotubes }\end{array}$ & $\begin{array}{l}\text { Lee et al } \\
(121)\end{array}$ & NA & $\begin{array}{l}\text { Nano- } \\
\text { material } \\
\text { manu- } \\
\text { facturing }\end{array}$ & $\begin{array}{l}\text { Exposed workers } \\
(\mathrm{N}=9) \text {; non-exposed } \\
\text { office employees } \\
(\mathrm{N}=4)\end{array}$ & $\begin{array}{l}\text { Oxidative stress biomarkers: increased levels of malondialdehyde (MDA), } \\
\text { 4-hydroxy-2-hexonal, and N hexanal in the exhaled breath condensate } \\
\text { of exposed workers compared to unexposed controls. }\end{array}$ \\
\hline \multirow[t]{2}{*}{$\begin{array}{l}\text { Multi-walled } \\
\text { carbon } \\
\text { nanotubes }\end{array}$} & \multirow[t]{2}{*}{$\begin{array}{l}\text { Shvedova et } \\
\text { al (127) }\end{array}$} & \multirow[t]{2}{*}{$\begin{array}{l}2-10 \mathrm{~nm} \times \\
\text { micrometer }\end{array}$} & \multirow[t]{2}{*}{$\begin{array}{l}\text { Manu- } \\
\text { facturing }\end{array}$} & \multirow[t]{2}{*}{$\begin{array}{l}8 \text { exposed workers; } \\
7 \text { non-exposed } \\
\text { controls }\end{array}$} & $\begin{array}{l}\text { Alterations in non-codingRNA and mRNA expression profiles showed a } \\
\text { set of miRNAs and their target genes with functions in cell cycle regula- } \\
\text { tion/progression/control, apoptosis and proliferation. }\end{array}$ \\
\hline & & & & & $\begin{array}{l}\text { The identified pathways and signaling networks also revealed MWCNT } \\
\text { potential to trigger pulmonary and cardiovascular effects as well as car- } \\
\text { cinogenic outcomes. }\end{array}$ \\
\hline \multirow{3}{*}{$\begin{array}{l}\text { Multi-walled } \\
\text { carbon } \\
\text { nanotubes }\end{array}$} & \multirow[t]{3}{*}{$\begin{array}{l}\text { Vlaanderen } \\
\text { et al (122) }\end{array}$} & \multirow[t]{3}{*}{ NA } & \multirow[t]{3}{*}{$\begin{array}{l}\text { Manu- } \\
\text { facturing }\end{array}$} & \multirow{3}{*}{$\begin{array}{l}\text { Exposed workers } \\
(\mathrm{N}=22) ; \text { non-exposed } \\
\text { controls }(\mathrm{N}=39)\end{array}$} & $\begin{array}{l}\text { Respiratory effect biomarkers: decreased Fractional Ehaled NO } \\
\text { concentrations. }\end{array}$ \\
\hline & & & & & $\begin{array}{l}\text { Immunological biomarkers: increased concentration of C-C motif ligand } \\
\text { and 20, basic fibroblast growth factor (FGF), and soluble IL-1 receptors } \\
\text { in EBC. }\end{array}$ \\
\hline & & & & & $\begin{array}{l}\text { Hematological alterations: significant depression in neutrophils and sig- } \\
\text { nificant elevation in monocytes, mean platelet volume, immature platelet } \\
\text { fraction, and immature reticulocytes fraction with increasing exposure } \\
\text { to MWCNT. }\end{array}$ \\
\hline $\begin{array}{l}\text { Multi-walled } \\
\text { carbon } \\
\text { nanotubes }\end{array}$ & $\begin{array}{l}\text { Ghosh et al } \\
\text { (128) }\end{array}$ & $\begin{array}{l}200 \mathrm{~nm} \\
-100 \mu \mathrm{m}\end{array}$ & $\begin{array}{l}\text { Manu- } \\
\text { facturing }\end{array}$ & $\begin{array}{l}\text { Exposed workers } \\
\text { ( } \mathrm{N}=24) ; \text { Non-exposed } \\
\text { controls ( } \mathrm{N}=43) \text {. } \\
\text { Follow-up (after } 4 \\
\text { months): exposed } \\
\text { workers ( } \mathrm{N}=11) ; \text { Non- } \\
\text { exposed controls } \\
(\mathrm{N}=4) \text {. }\end{array}$ & $\begin{array}{l}\text { Significant changes in methylation of at least one or more CpG sites } \\
\text { were observed for all the genes studied (ENMAT/ATM, SKI, DNMT1, and } \\
\text { HDAC4) in MWCNT exposed workers. }\end{array}$ \\
\hline
\end{tabular}

Multi-walled carbon nanotubes

Carbon nanotubes / carbon nanofibers

Carbon
nanotubes /
carbon
nanofibers
Carbon
nanotubes /
carbon
nanofibers

Silver
Various nanoma-
terials (Ag, iron-
oxide, nanogold

oxide, nanogold

CNT, $\mathrm{TiO}_{2}, \mathrm{SiO}_{2}$ )

Various nanomaterials $\left(\mathrm{CNT}, \mathrm{TiO}_{2}\right.$, $\mathrm{SiO}_{2}$, and others ie, nanoresins, Ag, nanogold, nanoclay, nanoalumina and metal oxides)

$\begin{array}{lll}\begin{array}{l}\text { Kuijpers et al } \\ \text { (125) }\end{array} & \begin{array}{l}\text { Manu- } \\ \text { facturing }\end{array} & \begin{array}{l}\text { Exposed workers } \\ (\mathrm{N}=22) ; \text { Unexposed } \\ \text { controls }(\mathrm{N}=42) .\end{array}\end{array}$

Follow-up (after 5 months): exposed workers $(\mathrm{N}=13)$;

Non-exposed workers $(\mathrm{N}=6)$ Exposed workers

$\begin{array}{llll}\text { Beard et al } & 1.5-110 \mathrm{~nm} \times & \begin{array}{l}\text { Manu- } \\ \text { (124) }\end{array} & 3.3 \mu \mathrm{m}-1 \mathrm{mn} \\ & & \begin{array}{l}\text { facturing } / \\ \text { handling }\end{array} & \begin{array}{l}\text { Exposed workers } \\ (\mathrm{N}=90)\end{array} \\ & & & \end{array}$

Dahm et al (2) $1.5-110 \mathrm{~nm}$ $3.3 \mu \mathrm{m}-1 \mathrm{~nm}$

Manufacturing

Exposed workers handling

Schubauer- $\quad 1.5-110 \mathrm{~nm}$ Berigan et al $3.3 \mu \mathrm{m}-1 \mathrm{~nm}$

Manu(117) handling

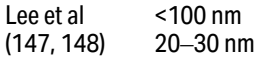

Manufacturing

Exposed workers ( $\mathrm{N}=124)$; non$(\mathrm{N}=77)$

Manufacturing handling

Exposed workers $(\mathrm{N}=227) ;$ nonexposed controls $(\mathrm{N}=137)$
Dose-dependent upward trend in the concentration of endothelial damage marker ICAM-1 in MWCNT exposed workers compared to unexposed controls.

Biomarkers associated with at least three CNT/carbon nanofiber metrics in sputum: type IV collagenase/matrix metalloproteinase-2 (MMP-2), IL-18, glutathione peroxidase (GPx), myeloperoxidase, and superoxide dismutase (SOD).

In blood: MMP-2, matrix metalloproteinase-9, metalloproteinase inhibitor 1/tissue inhibitor of metalloproteinases 1, 8-hydroxy-2'deoxyguanosine, GPx, SOD, endothelin-1, fibrinogen, ICAM-1, VCAM-1, and von Willebrand factor.

Only $18 \%$ of investigated workers had CNT/F present in sputum samples. When subdivided in industry, $18 \%, 11 \%$ and $27 \%$ of the participants within the primary manufacturing, hybrid, and secondary manufacturing facilities had CNT/F present in their sputum.

Inhalable elemental carbon (EC) concentration and duration of work with CNT/F were positively associated with the development of respiratory allergies.

Resting heart rate (RHR) was positively related to inhalable and respirable EC concentrations, while hematocrit counts showed a positive relationship with CNT/F structure count concentrations.

Biological monitoring of silver: 0.034 and $0.0135 \mu \mathrm{g} / \mathrm{ml}$ in blood; none in urine.

The decreases in the changes in SOD, GPx between baseline and the 6-month follow-up in the exposed group were significantly greater than in unexposed controls.

VCAM between baseline and the 6-month follow-up in the exposed group was significantly greater than in the unexposed controls.

Increased levels of anti-oxidant enzymes (SOD, GPx) were found in exposed workers (directly and indirectly handling nanomaterials) compared to unexposed controls.

Increased expression of cardiovascular markers: fibrinogen, IL-6, ICAM were found in exposed workers compared to unexposed controls. 
Table 1. continued.

\begin{tabular}{|c|c|c|c|c|c|}
\hline Nanomaterial ${ }^{\mathrm{a}}$ & Reference & Particle size & $\begin{array}{l}\text { Workplace / } \\
\text { operations }\end{array}$ & $\begin{array}{l}\text { Sample size exposed/ } \\
\text { non-exposed workers }\end{array}$ & Findings \\
\hline \multirow{3}{*}{$\begin{array}{l}\text { Titanium dioxide, } \\
\text { silica dioxide, } \\
\text { indium tin oxide } \\
\text { (ITO) }^{\mathrm{e}}\end{array}$} & \multirow[t]{3}{*}{ Liou et al (38) } & \multirow[t]{3}{*}{$<100 \mathrm{~nm}$} & \multirow[t]{3}{*}{$\begin{array}{l}\text { Manu- } \\
\text { facturing }\end{array}$} & \multirow{2}{*}{$\begin{array}{l}\text { Workers exposed } \\
\text { to } \mathrm{TiO}_{2}-(\mathrm{N}=26) \\
\mathrm{SiO}_{2}-(\mathrm{N}=31)\end{array}$} & $\begin{array}{l}\text { Exposure to } \mathrm{TiO}_{2-}^{-}, \mathrm{SiO}_{2-}^{-} \text {, and ITO-ENM resulted in significantly higher } \\
\text { oxidative biomarkers such as urinary 8-OHdG and } \mathrm{EBC} 8 \text {-isoprostane. }\end{array}$ \\
\hline & & & & & \multirow{2}{*}{$\begin{array}{l}\text { Global DNA methylation levels were significantly lower in } \mathrm{SiO}_{2} \text { and ITO } \\
\text { exposed group than in unexposed controls. }\end{array}$} \\
\hline & & & & $\begin{array}{l}\text { ITO-ENM }(\mathrm{N}=30) \\
\text { non-exposed } \\
\text { controls }(\mathrm{N}=43)\end{array}$ & \\
\hline $\begin{array}{l}\text { Titanium dioxide, } \\
\text { silica dioxide, } \\
\text { indium tin oxide }\end{array}$ & Liou et al (39) & $<100 \mathrm{~nm}$ & & $\begin{array}{l}\text { Workers exposed to } \\
\mathrm{TiO}_{2}(\mathrm{~N}=32) ; \mathrm{SiO}_{2} \\
(\mathrm{~N}=39) ; \text { ITO- } \mathrm{ENM} \\
(\mathrm{N}=56) ; \text { non-exposed } \\
\text { controls }(\mathrm{N}=100)\end{array}$ & $\begin{array}{l}\text { Exposure to } \mathrm{TiO}_{2}, \mathrm{SiO}_{2} \text {, and ITO resulted in significant lower antioxidant } \\
\text { enzymes (GPx and } \mathrm{SOD} \text { ) and higher oxidative biomarkers 8-hydroxy- } \\
\text { deoxyguanosine (8-oxodG) in urine, blood and white blood cells than in } \\
\text { unexposed controls. }\end{array}$ \\
\hline $\begin{array}{l}\text { Various (CNT, tita- } \\
\text { nium dioxide, silver, } \\
\text { indium tin oxide) }\end{array}$ & Wu et al (66) & NA & $\begin{array}{l}13 \text { factories } \\
\text { manuf- } \\
\text { acturing } \\
\text { ENM }\end{array}$ & $\begin{array}{l}\text { Exposed workers } \\
(\mathrm{N}=241) ; \text { non- } \\
\text { exposed controls } \\
(\mathrm{N}=196)\end{array}$ & $\begin{array}{l}\text { Nano } \mathrm{TiO}_{2} \text { exposure was significantly associated with fractional exhaled } \\
\mathrm{NO} \text { as a diagnostic test of airway inflammation. }\end{array}$ \\
\hline
\end{tabular}

a Listed in order of commercial tonnage (from most to least).

${ }^{\mathrm{b}}$ Analyzed as silica; most likely from discussion as amphorous silica.

c Particle size distributions varied between different job tasks and locations.

d See reference 39 for more details; most particles $<100 \mathrm{~nm}$.

e ITO particle size not available.

in peripheral blood eosinophil count in exposed workers as a sign of nanomaterial induced inflammation (20). These findings were supported in the previous study of other possible pro-inflammatory biomarkers, which found a significant increase in circulating pro-inflammatory cytokines, ie, interleukin (IL)-1 $\beta$, IL-6, IL-8, macrophage inflammatory protein (MIP)-1 $\beta$, and tumor necrosis factor (TNF)- $\alpha$ in exposed carbon black workers compared to controls (20). These results are in line with those reported in animal investigations demonstrating pulmonary inflammation $(19,22-24)$ associated with a severe tissue damage $(25,26)$ and a significant increase in serum proinflammatory biomarkers, including pro-inflammatory cytokines in treated animals $(20,27-29)$.

Although further investigation seems necessary, such preliminary results can suggest that carbon black nanomaterials may be responsible, at least in part, for the reduction of pulmonary function and inflammatory response detected in exposed workers. Concerning a possible dose-response relationship, the limited available data on environmental exposure concentrations, as well as the lack of biological monitoring information on occupational exposure, prevent the achievement of definite conclusions in that regard. Pulmonary functional alterations observed in workers exposed at concentrations greater than the adopted TLV underlines the importance of investigating high levels of exposure. However, from a precautionary perspective, preliminary knowledge regarding the toxicological behavior of ENM also requires investigation of possible adverse effects on workers exposed to low concentrations for long periods.

\section{Synthetic amorphous silica (SAS)}

Synthetic amorphous silica has been in commerce for $>80$ years. This silica polymorph is an intentionally manufactured material that does not contain measurable levels of crystalline silica $(30,31)$. It is a nanostructured material consisting of aggregates and agglomerates of primary particles that are generally $<100 \mathrm{~nm}$ (32). There are three categories of SAS based on manufacturing: pyrogenic $(7-50 \mathrm{~nm})$; precipitated $(5-100 \mathrm{~nm})$, and gels $(3-20 \mathrm{~nm})(30)$. A review of epidemiological studies and case reports of workers exposed to synthetic amorphous silica going back to 1932 failed to show conclusive evidence of fibrosis, but the data were limited $(30,33)$. The studies did not exclude the risk of chronic obstructive pulmonary disease (COPD) and emphysema, and none are informative with regard to carcinogenicity $(30,33)$.

For production workers exposed to nanoscale SAS, no explicit adverse effects have been found in recent epidemiological cross-sectional studies. However, one case series, Song et al (34), described seven female workers, employed in the same department of a print plant and exposed to $\sim 30$-nm-sized silica ENM in a polyacrylic ester. The workers had no protective measures for periods as long as 5-13 months. The workers developed shortness of breath and pleural effusions. Pathological examinations of the patients' lung tissue displayed nonspecific pulmonary inflammation, pulmonary fibrosis and foreign-body granulomas of the pleura (34). Electron microscopy and energy dispersive $x$-ray analysis identified and characterized silica-ENM primarily in macrophages, pulmonary micro-vessels, and pleural effusions. The findings suggest that these ENM may have contributed in part to the illness reported 
by these workers, although it is not clear if these ENM were amorphous silica (35). A cross-sectional study of $\mathrm{SiO}_{2}$-NP exposed workers had significantly greater cardiovascular related biomarkers, heart rate variability, vascular cell adhesion molecule (VCAM), and intercellular adhesion molecule (ICAM) than controls (36).

One hypothesis-generating study (37) demonstrated that workers employed in 14 factories in Taiwan who handled multiple ENM, including nanoscale silica, had reduced serum levels of antioxidant enzymes. Considering the key role of ENM induced reactive oxygen species (ROS) in tissue toxicity, possible biomarkers of early oxidative stress were specifically investigated in a subset of workers ( $\mathrm{N}=37)$ using $\mathrm{SiO}_{2}$-ENM (12-200 nm) (38). In this context, measurements of 8-hydroxydeoxyguanosine $(8-\mathrm{OHdG})$ in urine $(38,39)$, plasma, and white blood cells (39) and exhaled breath condensate levels of 8-isoprostane (38) were significantly higher compared to the controls, while levels of anti-oxidant enzyme activities were significantly decreased in the exposed group compared to controls (38). When two examinations were performed on workers handling $\mathrm{SiO}_{2}$-ENM at baseline and 6-month follow up, the depression of serum antioxidant enzymes levels, ie, superoxide dismutase and glutathione peroxidase, were significantly greater in exposed groups compared to controls (36). As regards epigenetic alterations, which may affect genetic regulation and cellular differentiation, a significantly lower global level of DNA methylation was observed in peripheral white blood cells of workers handling $\mathrm{SiO}_{2}$-ENM compared to controls. Interestingly, such alterations were inversely correlated with the urinary and white blood cell 8-OHdG concentrations (38).

These epidemiological findings (36-39) have been confirmed in animal models in which exposure to nanoscale SAS particles was reported to induce low systemic and negligible pulmonary toxicity (40-42). The particle's ability to distribute in lungs, lymphatic tissues, and major organs of excretion, such as the liver and kidneys, following inhalation exposure was limited $(43,44)$. However, there is evidence from in vivo studies that one type of SAS, fumed silica, has been shown to generate cytotoxicity and pro-inflammatory effects $(31,45-47)$.

Overall, epidemiological findings may support that one of the principal mechanisms of $\mathrm{SiO}_{2}$-ENM toxicity is the generation of reactive oxygen species and oxidative injury. This is the major mechanism by which ENM may induce adverse health effects and, in such effects, possible biomarkers may be found. Innovative effect biomarkers may be identified in investigations focused on ENM-induced epigenetic effects. These may include not only methylation changes at the global and repeated DNA level but also possible alterations in response to ENM exposure at specific loci. Addition- ally, these investigations indicate that oxidative DNA damage may have a role in inducing such phenomena. However, these latter issues need to be clarified with further research. Finally, no data are currently available concerning the exposure levels potentially responsible for such described alterations. The pathological alterations that occurred in workers exposed to ENM who were not wearing personal protective equipment (34, 35 ) suggest the need to verify the role of collective and individual exposure controls in managing the risk of possible ENM-induced adverse health effects.

\section{Aluminum oxide}

Aluminum oxide results from refined bauxite, which is subsequently reduced to aluminum (48). There have been no epidemiological studies of intentionally manufactured aluminum oxide nanomaterials. However, there have been occupational studies that have shown that inhaled aluminum oxide particles (size unspecified) are linked to pulmonary fibrosis, asthma, chronic obstructive lung diseases and possibly lung cancer (49-52). Ultrafine particles have been identified in primary aluminum smelters and pot rooms (53). Concerning animal data, pulmonary inflammation and cytotoxicity (54), an increase in the number of immune cells in BAL fluid $(55,56)$ and levels of IL-6, macrophage inflammatory protein- $1 \alpha$ (MIP-1 $\alpha$ ), and monocyte chemoattractant protein- $1 \alpha$ (GM-CSF) were reported after aluminum oxide ENM inhalation. Overall, the lack of epidemiological studies on possible adverse health effects prevents definite conclusions on the impact that aluminum oxide ENM may have on the health of exposed workers and possible markers indicative for early detection of biological alterations.

\section{Barium titanate}

Barium titanate (barium titanium trioxide) is a member of the large family of compounds with the general formula $\mathrm{ABO}_{3}$, known as perovskites (57). Barium titanate is a widely used electro-ceramic material that is increasingly used in biology and medicine. It is produced in a variety of ways and with a broad range of particle sizes, including some $<100 \mathrm{~nm}(57,58)$. There appears to be neither documentation of occupational exposures to barium titanate nanomaterials nor animal inhalation studies. However, a study of mice injected with hydroxyapatite-barium titanate composites (nano to submicron agglomerates) for implant testing indicated an absence of any inflammatory or adverse reactions (59). Considering the widespread application of this compound at the nanoscale, it seems important to plan future studies investigating early biological alterations in occupationally exposed populations. 


\section{Titanium dioxide}

There are four naturally occurring titanium dioxide polymorphs: rutile, anatase, brookite, and titanium dioxide (B) (14). Particle size plays an important role in many $\mathrm{TiO}_{2}$ applications. The major use of $\mathrm{TiO}_{2}$ is in pigments where particles in the size range of 200-300 $\mathrm{nm}$ are generally employed. Many other uses, eg, in the electronic field, involve particles $<100 \mathrm{~nm}$ (14). Epidemiological studies of $\mathrm{TiO}_{2}$ production workers show limited evidence of malignant or nonmalignant health effects, although the particle size was not specified (14, $60,61)$. In 2010, the IARC reviewed epidemiologic data and found inadequate evidence to classify $\mathrm{TiO}_{2}$ as a human carcinogen (12). However, lung tumors observed in rats following chronic inhalation of nano-sized $\mathrm{TiO}_{2}$ included squamous cell keratinizing cysts, bronchoalveolar adenocarcinomas, and squamous cell carcinomas $(62,63)$. These findings led the IARC to consider animal data sufficient for an evaluation of "possibly carcinogenic to humans" (14).

Epidemiological studies performed on nano- $\mathrm{TiO}_{2}$ production workers are generally cross-sectional in nature. These studies have not shown a clear pattern of health effects, although some biological alterations emerged as possible indicators of exposure and early effect. Pelclova et al (64) demonstrated that particles of rutile and/or anatase could be detected in the exhaled breath condensate (EBC) of exposed workers. The content of the metal in their breath was significantly higher compared to controls, suggesting a method of measurement to assess exposure to $\mathrm{TiO}_{2}$-ENM.

Zhao et al (65) recently investigated the pulmonary effects induced by $\mathrm{TiO}_{2}$-ENM in workers exposed in a packaging workshop to identify possible functional alterations and biomarkers associated with exposure (estimated mass concentration of $1.22 \mathrm{mg} / \mathrm{m}^{3}$ ). The authors found that the observed and predicted values of FVC, FEV1, peak expiratory flow (PEF), and forced expiratory flow (FEF) $25-75 \%$, were significantly reduced in exposed workers compared to the controls. In this study, pulmonary function test alterations were also confirmed by the decrease in serum levels of surfactant protein-D levels, which may be a preclinical lung damage biomarker caused by cell injury and/or decrease in number of type II alveolar epithelial cells. As a possible diagnostic test of airway inflammation, the fractional exhaled nitric oxide (FENO) measurement was significantly increased in workers exposed to $\mathrm{TiO}_{2}$-ENM (66). Additionally, leukotriene levels were significantly elevated in the EBC of exposed workers relative to controls and well correlated with workplace Ti concentrations (67). The possibility of using such biological alterations to monitor the early effects of nano- $\mathrm{TiO}_{2}$ exposures on workers deserves further investigation.
Regarding the cardiovascular effects, Ichihara et al (68) demonstrated that exposure to $\mathrm{TiO}_{2}$-ENM was associated with heart rate variabilities in workers involved in processing and handling such nanomaterials. Moreover, to support a possible role of $\mathrm{TiO}_{2}$-ENM in inducing cardiovascular alterations, Liao et al (36) and Zhao et al (65) demonstrated increased levels of VCAM-1, ICAM-1, and low-density lioprotein (LDL) as possible cardiovascular early disease biomarkers.

Concerning the role that systemic inflammatory as well as oxidative stress responses may have in determining possible adverse health effects, the concentrations of serum amyloid A (SAA) and high sensitivity-C reactive protein (CRP) were not significantly different between $\mathrm{TiO}_{2}$-ENM exposed and unexposed workers (65). Conversely, the serum levels of interleukin (IL)-8, IL-6, IL-1 $\beta$, TNF-a, and IL-10 as possible pro-inflammatory cytokines, as well as superoxide dismutase (SOD) and malondialdehyde (MDA), as oxidative stress indicators were demonstrated to be significantly associated with occupational exposure to $\mathrm{TiO}_{2}$-ENM (65).

In this regard, a significant increase in markers of oxidative stress damage of nucleic acids and proteins in the EBC was evident in the more exposed production workers, involved in micronation, calcination and other $\mathrm{TiO}_{2}$-ENM production activities, than in the lower exposed groups of research workers and controls (69). In another study, when a panel of biomarkers of lipid oxidation was investigated in the EBC of workers exposed to $\mathrm{TiO}_{2}$-ENM during production tasks as well as in office employees of the $\mathrm{TiO}_{2}$ production plant, significant dose-dependent increases were detected compared to unexposed controls $(70,71)$. In a recent investigation, occupational exposure to $\mathrm{TiO}_{2}$-ENM in manufacturing and/or handling facilities resulted in significantly higher oxidative biomarkers, such as urinary $8-\mathrm{OHdG}$ and EBC 8-isoprostane (38).

Such epidemiological findings are supported by extensive animal evidence concerning the deposition and bio persistence of $\mathrm{TiO}_{2}$-ENM in the pulmonary system (72-75) and the consequent development of inflammatory reactions $(72,76-82)$ with possible increased airway responsiveness (83) as well as acute or sub-acute airflow alterations (84). The findings of markers indicative of ROS and pulmonary inflammation (76, 78-80, $85)$, although reversible in some cases (86), make a suggestive case for $\mathrm{TiO}_{2}$ having pulmonary inflammogenic effects. Cardiovascular effects have been also reported in animals in which the inhalation of $\mathrm{TiO}_{2}$-ENM enhanced the phosphorylation levels of cardiac proteins (87) and impaired vasodilator response (88-91), which may be due to an increase in microvascular oxidative stress (92).

Overall, these findings support the need for future investigations primarily focused on early $\mathrm{TiO}_{2}$-ENM clinical effects on the respiratory and cardiovascu- 
lar systems. Additionally, inflammatory and oxidative stress early biomarkers should be explored in depth as early biological indicators of the health impact of such xenobiotics, considering their possible predictive role of adverse outcomes. See, for example, the role of CRP as a major cardiovascular risk factor (93).

A suitable dose-response relationship has not been definitively identified. Preliminary data suggest positive relationships between levels of exposure, peculiar to job tasks in NP settings and biological changes as demonstrated by higher levels of oxidative stress biomarkers in more exposed production workers $(0.13-0.76 \mathrm{mg} /$ $\mathrm{m}^{3}$ particle total mass concentration; mean particle number range $\left.0.29-2.48 \times 10^{4} / \mathrm{cm}^{3}\right)$, compared to lower exposed research workers $\left(0.16 \mathrm{mg} / \mathrm{m}^{3}\right.$ particle total mass concentration; mean particle number $1.32 \times 10^{4}$ / $\left.\mathrm{cm}^{3}\right)(69)$. These findings may give stimulus to in-depth exploration of dose-response relations with respect to biological markers of exposure such as the Ti concentration in EBC.

\section{Cerium dioxide}

Cerium dioxide $\left(\mathrm{CeO}_{2}\right)$ ENM are increasingly being used in industrial and commercial applications (94, 95); however, there are no epidemiological studies of workers exposed to $\mathrm{CeO}_{2}$ ENM. Various animal inhalation and intratracheal studies show pulmonary inflammation and fibrosis (96-100), from the accumulation of $\mathrm{CeO}_{2}$ ENM in the lung tissue (101), as well as surface functionalization of the particles $(96,102)$. Such inflammatory responses were characterized by increased polymorphonuclear neutrophils (PMN) and lactate dehydrogenase (LDH) levels, and augmented expression of CINC-1, CINC-2, and HO-1 in bronchial lavage fluids $(98,101)$. Extra-pulmonary toxicity and tubular degeneration leading to coagulative necrosis in the kidney were also observed (103).

\section{Zinc oxide}

Some workers exposed to $(\mathrm{ZnO})$ fume in welding and metal working operations have been shown to experience metal fume fever $(104,105)$. These $\mathrm{ZnO}$ fumes are comprised of a large proportion of NP (106). While such NP are considered combustion-derived, they may be considered "engineered" in the sense that, for welding to be effective, the appropriate specified temperature range of the materials needs to be achieved.

A study of 118 shipyard workers involved with welding and a comparison group of 45 office workers showed cardiovascular toxicity and alterations in various biomarkers [decreased cell viability, increased levels of 8-OHdG, IL-6 and nitric oxide in human coronary artery epithelial cells] (107). Exposures of the welders to particles were in the range of 5-160 nm (107). These results obtained with $\mathrm{ZnO}$ at the nanoscale confirmed the higher incidence of cardiovascular disease found in welders $(108,109)$.

Other than welding exposures, no epidemiological studies of occupational exposures to ZnO-ENM have been identified. An experimental study of $\mathrm{ZnO}$ fumes $\left(2.5 \mathrm{mg} / \mathrm{m}^{3}\right.$ and $5 \mathrm{mg} / \mathrm{m}^{3}$ for two hours) in 13 healthy non-smoking volunteers demonstrated the manifestation of fever and symptoms at the higher dose, as well as fever alone at the lower dose (110). Metal fumes generally contain NP. Exposure to $\mathrm{ZnO}$ at $5 \mathrm{mg} / \mathrm{m}^{3}$ $(60 \mathrm{~nm}$ count median diameter; $170 \mathrm{~nm}$ mass median diameter) resulted in elevated plasma levels of IL-6, as well as myalgias, cough, and fatigue (110). Prior to this study, an earlier investigation of $\mathrm{ZnO}$ exposure in human subjects produced a metal fume fever in four human volunteers ( 2 hours at $5 \mathrm{mg} / \mathrm{m}^{3}$ ) (110). More recently, a dose-dependent $\left(0.5-2 \mathrm{mg} / \mathrm{m}^{3}\right)$ increase in symptoms, ie, fever, throat irritation, cough, minor respiratory symptoms, as well as flu-like symptoms, were determined after 24-hour post $\mathrm{ZnO}$-ENM inhalation exposure (primary particle size of $\sim 10 \mathrm{~nm}$ for 4 hours) in healthy human volunteers (111). However, the most sensitive outcomes were the concentration dependent increase in both CRP and SAA levels determined in blood 24 hours after exposure, while all concentrations of $\mathrm{ZnO}$-ENM elicited significantly increases in neutrophils at the same time point (111).

In animals exposed to $\mathrm{ZnO}$-ENM, in addition to pulmonary inflammation and lung injury $(110,112)$, researchers have found degeneration and necrosis of the myocardia after sub-chronic conditions of exposure (112). After acute and sub-chronic exposures, the following biomarkers of inflammation were detected: increased white blood cell count in the peripheral blood of exposed animals (113), transient increases in total cells and neutrophil counts, and cytokine induced neutrophil chemoattractant (CINC-1, CINC-2) and heme oxygenase-1 (HO-1) in bronchoalveolar lavage fluid (BALF) $(114,115)$. Co-exposure of ZnO-ENM and toluene, at their respective permissible exposure level in the paint industry, was reported to potentially produce a progressive inflammatory and fibrotic response in the alveolar tissues of the lungs of co-exposed rats (116).

Overall, the effects observed in healthy humanvolunteer investigations suggest the occurrence of a systemic inflammation following ZnO-ENM exposure, which may be explained by either primary local inflammation of the respiratory tract/lung and secondary resorption of inflammatory markers or by primary systemic inflammation due to resorbed zinc ions (111). The lack of occupational epidemiological data could be addressed in future investigations aimed to define doseresponse relationships, as well as possible biomarkers, 
like acute phase proteins CRP and SAA, which could be easily employed in biological occupational monitoring and may be indicative not only of inflammatory reactions but also possible cardiovascular events.

\section{Carbon nanotubes and carbon nanofibers}

Carbon nanotubes (CNT) and carbon nanofibers (CNF) are relatively new commercial materials. Recent epidemiological studies have specifically investigated occupational populations exposed to CNT (117-120). It is important to note that there are many different types of CNT in commerce, and these studies generally did not distinguish the specific types of CNT, other than identifying multi-walled CNT (MWCNT). Additionally, some MWCNT have residual impurities derived from the manufacturing process that can influence their reactivity and, consequently, the induced biological alterations that may function as possible biomarkers. In a pilot study, Lee et al (121) failed to find significant changes in the pulmonary function, hematology, and blood chemistry in nine MWCNT manufacturing workers compared to four office workers.

In another study to assess markers of lung inflammation, differences in FENO were observed between MWCNT-exposed workers and controls, but no differences were evident in lung function or pneumo-proteins CC16, SP-A, and SP-D (122). The reduction in FENO concentrations due to MWCNT exposure suggest that MWCNT may have an inhibitory effect on nitric oxide synthase in the airways. Also, as further respiratory effect indicators, Fatkhutdinova et al (123), found that occupational exposure to MWCNT was associated with changes in fibrotic markers. A biomarker for interstitial lung disease, KL-6, was found in increased levels in collected sputum samples in exposed workers manufacturing MWCNT compared to controls (123). Profibrotic inflammatory biomarkers, such as the cytokines IL-1 $\beta$, IL-4, IL-5, IL-6, IL-8 and TNF- $\alpha$ were significantly higher in sputum of exposed workers than controls; and serum IL- $1 \beta$, IL-4 and TNF- $\alpha$ were also significantly elevated in the exposed group (123).

Concerning alterations in immunological and hematological parameters, the comparison between MWCNTexposed workers and age- and gender-matched controls showed significant upward dose-dependent trends for blood concentrations of various immunological indicators, including $\mathrm{C}-\mathrm{C}$ motif ligand 20 , basic fibroblast growth factor, and soluble IL-1 receptors (122). Significant decrease in neutrophils and elevation in monocytes, mean platelet volume, immature platelet fraction, and immature reticulocytes fraction were evident with increasing exposure to MWCNT (122). Beard et al (124) investigated the relationship between CNT and CNF exposure and biomarkers of fibrosis, inflammation, and oxidative stress in workers employed in manufacturing, using or distributing CNT and CNF. Variable percentages of the workforce employed in such facilities (up to 27\%), had CNT and CNF present in the sputum samples as internal dose indicators (2). CNT and CNF exposure was more consistently associated with sputum fibrosis and oxidative stress biomarkers than inflammation and cardiovascular biomarkers, ie, 8-OHdG, SOD, fibrinogen, and VCAM-1 (124). In blood, positive associations were observed between exposure and biomarkers from all the above-mentioned domains, including KL-6, CRP, ICAM-1 and VCAM-1 (124). Investigating the same workforce enrolled in the Beard study (124), SchubauerBerigan et al (117) found that the inhalable elemental carbon (EC) concentration and duration of work with CNT and CNF were positively associated with the development of respiratory allergies.

As regards cardiovascular adverse effects, a recent study (125) investigated the associations between MWCNT-exposure and biomarkers of cardiovascular risk. The authors found a significant dose-dependent upward trend in the concentration of endothelial damage marker ICAM-1 in 22 MWCNT-exposed workers, compared to age-/gender-matched unexposed controls (125). This may indicate a MWCNT-induced endothelial activation and an increased inflammatory state, which may be related to cardiovascular effects. Additionally, in another study, resting heart rate was positively related to inhalable and respirable EC concentrations (used to quantify CNT and CNF concentrations), while hematocrit counts showed a positive relationship with CNT and CNF structure counts (117).

Concerning oxidative stress reactions, MWCNT manufacturing workers had significantly higher levels of the MDA, 4-hydroxy-2-hexenal (4-HHE) and n-hexanal levels in EBC than office workers (121). Low levels of residual metal catalyst were found in air and blood, and blood molybdenum was well correlated with MDA and n-hexanal concentrations, suggesting a possible role of such metal contamination in affecting the toxicological profile of MWCNT (121). Although the study by Lee et al (121) failed to show adverse health effects, it indicated that early biomarkers of effect can be determined in the collected biological matrices. These markers were not necessary indicative of pathologic changes or early adverse effects. The markers collected in the EBC are established indicators of oxidative stress, although they may not be specific for MWCNT exposure. The use of aldehydes as dependent variables is based on their relationship with inflammation and ROS produced by activated inflammatory cells. While ROS formation is a normal physiologic process that occurs in every cell, increased levels of ROS can initiate harmful pathophysiological effects (118). Additionally, there is increasing evidence that aldelydes generated during the process 
of lipid peroxidation are also involved in many of the pathophysiological effects associated with oxidative stress in cells and tissues (119). Lipid peroxidation is one of the major mechanisms of ROS damage, and it occurs when oxidation of cell membranes initiates a chain reaction, which leads to the formation of aldehydes such as MDA, 4-HHE and n-hexanal such as observed in the Lee et al (121) study.

The case for risk of carcinogenicity is less clear, but may be a function of the type of CNT. In this regard, the recent IARC evaluation for CNT found that there is inadequate evidence in humans for the carcinogenicity of CNT, although there is sufficient evidence in experimental animals for the carcinogenicity of MWCNT-7 (126). For this reason, MWCNT-7 have been classified as possibly carcinogenic to humans (Group 2B), while MWCNT other than MWCNT-7 and single-walled carbon nanotubes are not classifiable as to their carcinogenicity to humans (Group 3) (126).

The whole blood gene expression profiling may also act as a tissue surrogate and may provide a powerful and an informative approach to investigate various disease conditions and identity biomarkers (127). Shvedova et al (127), in this regard, investigated the global noncoding-RNA and microRNA expression profiles in blood of exposed workers, having direct contact with MWCNT aerosol for $\geq 6$ months and compared these profiles with those of unexposed professional and/or technical staff. Interestingly, the identified pathways and signaling networks revealed the potential for MWCNT to exert pulmonary and cardiovascular adverse effects, as well as to trigger carcinogenic outcomes in humans. Epigenetic alterations in blood cells, induced by occupational exposure to CNT, could characterize another focus for biological monitoring research. In this perspective, Ghosh et al (128) investigated whether exposure to MWCNT in the workplace may induce DNA methylation changes at the global and/or gene-specific level in some functionally important genes in peripheral blood cells. The authors identified alterations on $\mathrm{CpG}$ sites in the promoter regions of functionally important genes in peripheral blood cells involved in the epigenetic machinery (ie, DNMT1, HDAC4), in the DNA damage response and G1/S transition in the cell cycle (ie, ATM), as well as in oncogenic activity (ie, SKI). The detected methylation alterations might inhibit or promote the gene expression of the corresponding genes.

The biomarker findings in studies of workers exposed to CNT are consistent with pathological findings identified in studies of laboratory animals exposed via inhalation to CNT that reported pulmonary inflammation, increased collagen thickness, and robust inflammatory response with severe oxidative stress leading to fibrosis and formulation of granulomatous lesions (120, 123, 129-140). In this scenario, Thelper (Th) 2-depen- dent type 2 immune pathways have been recognized as important drivers for the development of CNT-induced fibrosis (120). Upon stimulation, activated Th2 immune cells and type 2 cytokines interact with inflammatory and tissue repair functions to stimulate an overzealous reparative response to tissue damage, leading to organ fibrosis. Some of the animal studies also showed systemic inflammation (141), genotoxic effects (142) and an impairment in vascular smooth muscle reactivity (143), but also an immunosuppressive role of CNT exposure (144) and a carcinogenic potential due to interference with the mitotic spindle apparatus (145).

Overall, it can be concluded that at present there are no reported overt adverse effects in workers exposed to CNT. There is a consistent pattern of findings indicating that pulmonary inflammation and fibrosis could be potential outcomes in exposed populations, depending on the exposure level and duration of exposure (117, 124). Some fibrosis, inflammatory and oxidative stress biomarkers have been identified to be more strongly associated with CNT and CNF exposure $(117,124)$; however, to date, the lack of environmental or internal dose-exposure measurements prevents the identification of suitable dose-response relationships. Future research should clarify biological changes with respect to different exposure metrics, ie, environmental EC levels, count of CNT in sputum samples, as well as possible confounding functions due to possible metal contaminations of CNT that may bias the CNT health impact as well as biomonitoring results. Future research on global gene expression profiles as well as epigenetic effects induced by CNT may provide information to get molecular insights into the CNT-induced toxicity and pathogenesis in humans and to verify in large-scale prospective studies their validity and potential applicability as exposure and effect markers in occupationally exposed subjects (127).

\section{Silver nanoparticles}

Silver ENM (Ag-ENM) are the most common ENM in consumer products (www.nanoproject.org). Demand is growing for a wide variety of silver nanostructures, such as spheres and wires (146). A few health studies have focused on workers explicitly exposed to Ag-ENM $(36,147,148)$. Two of the studies reported on the same sample of two workers, employed for seven years in silver nanomaterial manufacturing, who were exposed to 20-30-nm-sized Ag-ENM at concentrations of 0.1 and $0.4 \mu \mathrm{g} / \mathrm{m}^{3}$ respectively, in their facility $(147,148)$. The workers showed no significant adverse changes in their health status $(147,148)$. In another study, nanomaterial handling workers in 14 manufacturing facilities in Taiwan were stratified for Ag-ENM ( $\mathrm{N}=6$ workers); significant increases were detected in cardiovascular 
disease biomarkers, VCAM and IL-6, and in reduction in heart rate frequency (36).

Concerning animal investigations, toxicity in the lungs, including inflammatory reactions and histopathological alterations (149-158) were reported to be responsible for pulmonary functionality alterations $(155$, $159)$ or allergic responses (160): however, other investigations have failed to detect hematological effects, systemic alterations, and pulmonary function test changes after Ag-ENM exposure $(161,162)$. Histopathological changes in the kidney and liver (bile duct hyperplasia and necrosis) were identified after inhalation exposures, such as extra-pulmonary effects $(155,158,159)$. Researchers have also reported changes in the expression of genes involved in xenobiotic metabolism and in the development and integrity of motor neurons; intracellular molecular patterns that regulate diverse cellular processes, including morphology, adhesion, motility; and apoptosis potentially related to neurotoxic and immunotoxic effects $(163,164)$.

The lack of human data relative to this widespread ENM requires further investigation on potential health effects in exposed workers and on the selection of possible biomarkers. Animal preliminary findings may be helpful to guide the verification of possible biological changes in humans.

\section{Discussion}

Understanding the effects of ENM in exposed subjects is becoming a public and occupational health priority due to the widespread application of nano-enabled products and the increased likelihood for consumer and workplace exposures. Although the number of currently available occupational field and epidemiological studies is quite limited, preliminary considerations regarding the possible health impact of ENM and biomarkers of effect can lead future investigations.

\section{Summary of data and occupational health considerations}

A summary of the findings for each of the nine high volume ENM is shown in table 2. The third column shows pathological effects in workers in epidemiological studies. That is, whether a study was identified that had significant pathologic effects related to exposure to an ENM. The fourth column reports epidemiological studies that identified a change of potential biomarkers of adverse effects.

Overall, to date there is limited evidence of adverse health effects in workers exposed to any of the most used ENM. All of the substances in table 2 except CNT have had long periods of use in some form (where the primary particle may have been $<100 \mathrm{~nm}$ ) and, hence long periods of worker exposure. Much of that exposure was to agglomerates in the micron-size range, and most of the studies did not clarify particle size, preventing the extrapolation of suitable conclusions for the toxicological profile of the nanoscale size of the chemical substances. The strongest historical findings are nonmalignant respiratory disease in workers exposed to carbon black and metal fume fever in workers exposed to zinc oxide. Furthermore, explicit pathologies induced by ENM exposure have not yet been demonstrated in studies of exposed workers. The respiratory system has been reported as the primary target organ for the inflammogenic potential of both carbon-, and metal- or metal-oxide-based ENM in workplace and experimental settings, although some conflicting evidence in this regard may be due to the different physico-chemical characteristics of ENM, in terms of particle size (149), surface functionalization/coating $(56,77,96,102)$, solubility (40), particle dispersion (114), residual impurities (121) as well as level and duration of exposures (129). This is important information considering that the respiratory tract is the primary route of entry of ENM in occupational settings. Additionally, the relevance of the physico-chemical characterization of ENM in affecting their toxicological profile raises some concerns regarding the generalizability of findings obtained in occupational exposure settings where multiple ENM coexposures may occur or where too few individuals work with a single agent preventing assessment of differences between chemicals in a meaningful way $(37,165)$.

Although the mechanisms for ENM-induced health effects are not fully known, the persistent inflammatory and related oxidative stress reactions induced by ENM may determine alterations in lung functionality, as reported in workers exposed to carbon black (20) or to $\mathrm{TiO}_{2}$-ENM (65). In line with these results, inflammatory responses induced by ENM exposure, and direct lung tissue damage exerted by nano-sized particle deposition and biopersistence in alveoli and bronchial walls $(25$, $54,72,101)$, were reported to result in fibrogenicity and increased airway hyperresponsiveness in laboratory animals $(83,97,120,129,155,159)$. The animal inhalation studies generally supported the human epidemiological biomarker findings and showed further significant effects for endpoints not yet seen in workers. In this regard, Th2dependent type immune pathways have been indicated as potential triggers for the development of CNT-induced fibrosis (120). The idea that ENM may have a fibrogenic function in exposed workers may be confirmed by epidemiological findings of increased levels of pro-fibrotic markers in serum and sputum of MWCNT-handling workers $(123,124)$ and by RNA transcriptional analysis (127). Various findings are highly suggestive of the potential for cardiovascular dysfunction resulting from a 
Table 2. Summary of epidemiological and human data for engineered nanomaterial (ENM) by commercial volume. [NA=not available]

\begin{tabular}{|c|c|c|c|}
\hline Nanomaterial $^{\mathrm{a}}$ & $\begin{array}{l}\text { World commercial } \\
\text { tonnage (tons) }\end{array}$ & $\begin{array}{l}\text { Epidemiologic findings of } \\
\text { pathologic effects in workers }\end{array}$ & $\begin{array}{l}\text { Potential biomarkers of adverse effects in epidemiological } \\
\text { studies of workers }\end{array}$ \\
\hline Carbon black & 9600000 & $\begin{array}{l}\text { Pulmonary function test } \\
\text { alterations }\end{array}$ & Inflammatory biomarkers: white blood cell count; pro-inflammatory cytokines. \\
\hline $\begin{array}{l}\text { Synthetic } \\
\text { amorphous silica }\end{array}$ & 1500000 & NA & $\begin{array}{l}\text { Oxidative stress biomarkers: urinary 8-hydroxydeoxyguanosine }(8-\mathrm{OHdG} \text { ) and } \\
\text { exhaled breath condensate (EBC); serum anti-oxidant enzymes }\end{array}$ \\
\hline $\begin{array}{l}\text { Aluminum oxide } \\
\text { Barium titanate } \\
\text { Titanium dioxide }\end{array}$ & $\begin{array}{l}200000 \\
15000 \\
10000\end{array}$ & $\begin{array}{l}\text { NA } \\
\text { NA } \\
\text { Pulmonary function test } \\
\text { alterations; heart rate variabilities }\end{array}$ & $\begin{array}{l}\text { Epigenetic effects: global DNA methylation } \\
\text { NA } \\
\text { NA } \\
\text { Pulmonary disease biomarkers: serum surfactant protein-D levels; nitric oxide } \\
\text { and leukotriene levels in EBC }\end{array}$ \\
\hline
\end{tabular}

Cardiovascular disease biomarkers: intercellular adhesion molecule 1 (ICAM-1); vascular cell adhesion protein 1, (VCAM-1); LDL

Inflammatory and oxidative stress biomarkers: pro-inflammatory cytokines, SOD and malondialdehyde serum levels; $E B C$ markers of oxidative damage of nucleic acids, proteins, and lipids; and 8-isoprostane; urinary 8-OHdG

$\begin{array}{lll}\begin{array}{l}\text { Cerium dioxide } \\ \text { Zinc oxide }\end{array} & 10000 & \text { NA } \\ & 8000 & \begin{array}{l}\text { Metal fume fever in healthy subjects } \\ \text { exposed to fumes containing ZnO- } \\ \text { ENM (not occupational) }\end{array} \\ \text { Carbon nanotubes/ } & \text { 100-3000 } & \text { NA }\end{array}$
nanofibers (not occupational)

Inflammatory biomarkers: blood C-reactive protein and serum amyloid A concentrations; neuthrophils count (not occupational data)

Pulmonary biomarkers: exhaled nitric oxide; $\mathrm{KL}-6$ in sputum

Cardiovascular biomarkers: ICAM-1; VCAM-1

Hematological biomarkers: blood cell count; immature cell fractions

Inflammatory and oxidative stress biomarkers: $\mathrm{C}-\mathrm{C}$ motif ligand 20 , basic fibroblast growth factor, and soluble interleukin (IL)-1 receptors in blood; IL-1 1 , IL-4, IL-5, IL-6, IL-8 and TNF $\beta$ cytokines in blood and sputum; malondialdehyde, 4-hydroxy-2-hexenal and $\mathrm{n}$-hexanal levels in EBC

Epigenetic biomarkers: gene-specific DNA methylation in peripheral blood cells Silver NA NA

a Listed in table by tonnage (7).

systemic inflammatory status following pulmonary exposure $(89,90,112,117,124,125,146,166)$.

\section{Biological monitoring implications}

Overall, considering the central role of the respiratory system in the toxicokinetic and toxicodynamic profile of ENM, the EBC, which needs further validation, has been proposed as a possible biological matrix to detect biomarkers of exposure, ie, the titanium content (64) and early effect, ie, alterations in pro-inflammatory, oxidative stress indicators $(66,67,69-71,121,122)$, as well as lung damage biomarkers (SP-D) (65). Additionally, nucleic acid, and protein and lipid oxidation biomarkers have been proposed as possible indicators of the oxidative stress reactions induced by ENM in the pulmonary system that can be assessed in EBC (69-71, 121). Moreover, considering that the persistence of inflammation and oxidative stress in the lungs may have a "systemic" impact on exposed organisms, biological monitoring investigations should consider biomarkers of systemic inflammatory and oxidative stress response in serum and changes in blood cell counts. This recommendation is supported by preliminary results demonstrating a significant association between occupational levels of exposure and increased serum concentrations of inflammatory cytokines, alterations in oxidative stress indicators, including anti-oxidant enzymes, and changes in blood cell count, ie, neutrophil reduction, and monocytes and reticulocyte increase in workers (20, $36,65,122-124)$.

Early biological alterations of blood parameters correlated to the cardiovascular functionality, ie, VCAM and ICAM concentrations as well as modifications in heart rate variability have also been explored in early human investigations on ENM toxicity with positive results for nano-silica, $\mathrm{TiO}_{2}$, and CNT $(20,65,68$, $117,125)$. In line with such epidemiological data, an impaired vasodilator response due to an increase in microvascular oxidative stress or altered circulations mediators was detected in experimental animals (88-92, 167). Few human studies reported data concerning the effects of ENM exposure and CRP, a well-known cardiovascular risk factor and an easy biomarker to measure in blood samples. All these issues stress the need to examine the role of ENM exposure on the cardiovascular system, considering the possible severe implications of such alterations on the health of exposed workers, and underline the need to focus additional investigations on more easily applicable biological indicators.

Emerging scientific evidence demonstrates that environmentally-induced epigenetic alterations may play a role in the manifestation of a number of human diseases, including cancer, mental disorders, obesity, and other severe conditions (168). Although the epidemiological data concerning epigenetic changes resulting from ENM 
exposure are preliminary $(38,127,128)$, future testing will be useful to help distinguish between adverse health effects induced by ENM exposure compared to adaptive changes. However, to initiate epigenetic toxicity monitoring for ENM exposure, it seems necessary to clarify ENM effects on the epigenome and define robust causal links between exposure, epigenetic changes and adverse phenotypic endpoints to develop improved assays to test such endpoints (169).

Additionally, considering the possible carcinogenic potential recognized for some types of ENM, ie, MWCNT-7 (126) and $\mathrm{TiO}_{2}$-ENM (129), it may be important to define early ENM biomarkers of genotoxicity. Testing this important toxicological aspect is crucial in safety assessment of new ENM compounds and products and may influence an approach to define suitable strategies for risk assessment and management in occupational settings.

\section{Future research needs}

This review revealed a need for robust longitudinal epidemiologic studies with clear exposure characterization, including particle size, extent of agglomeration, and other relevant physicochemical parameters. Of particular importance, studies that found strong evidence of adverse effects in animals should be verified/clarified in occupational field investigations. Also of concern, barium titanate, one of the ENM with significant commercial tonnage, has not been investigated for exposures or health effects; both animal and human studies should be conducted. Additionally, for cerium oxide, there is a need for epidemiological studies.

Most of the epidemiological biomarker studies on workers handling ENM are cross-sectional in nature. Among these studies, there were significant findings of biomarkers in exposed workers when compared to controls. This was true for markers of oxidative-stress with silica and $\mathrm{TiO}_{2}$ and for pulmonary, immunological and cardiovascular markers with CNT. Very few studies reported on dose-response gradients between workers in the same job profile with different exposure levels. Unfortunately, the limited data on environmental exposure levels of different ENM and biological information concerning internal doses, prevents the extrapolation of suitable dose-response relationships and the ability to define ranges of possible "dangerous exposure concentrations" (170). Having this information would allow for a reasonably accurate quantitative estimate of the occupational risks at the group and/or individual level. This seems an even more challenging issue, considering the difficulties in establishing dose-metric parameters that can calculate an ENM biologically effective dose due to the extremely variable physico-chemical characterizations of such chemicals. Future investigations should be aimed at clarifying these aspects to achieve better risk assessment and management strategies in workplaces.

\section{Concluding remarks}

As an overall conclusion, this paper takes the approach that it is not appropriate to address the question of whether there are adverse effects occurring in workers exposed in general to ENM, rather, each ENM should be investigated separately. Significant adverse indicators for specific ENM have been reported in epidemiologic and human case studies. Continuation of the use of precautionary controls for each ENM is warranted while further study of potential health effects proceeds.

\section{Disclaimer}

The findings and conclusions in this report are those of the author(s) and do not necessarily represent the views of the US National Institute for Occupational Safety and Health.

\section{Acknowledgements}

The authors thank William Boyes, Vincent Castranova, Michael Riediker, Eileen Kuempel, Laura Hodson, and Aaron Erdely for their comments on earlier drafts and Amanda Keenan and Amanda Stammer for processing the manuscript.

\section{References}

1. Vance ME, Kuiken T, Vejerano EP, McGinnis SP, Hochella MF Jr, Rejeski D et al. Nanotechnology in the real world: redeveloping the nanomaterial consumer products inventory. Beilstein J Nanotechnol 2015 Aug;6:1769-80. https://doi.org/10.3762/bjnano.6.181.

2. Dahm MM, Schubauer-Berigan MK, Evans DE, Birch ME, Bertke S, Beard JD et al. Exposure assessments for a cross-sectional epidemiologic study of US carbon nanotube and nanofiber workers. Int $\mathrm{J}$ Hyg Environ Health 2018 Apr;221(3):429-40. https://doi.org/10.1016/j. ijheh.2018.01.006.

3. Schulte PA, Geraci CL, Murashov V, Kuempel ED, Zumwalde RD, Castranova V et al. Occupational safety and health criteria for responsible development of nanotechnology. J Nanopart Res 2014;16:2153. https://doi. org/10.1007/s11051-013-2153-9.

4. Schulte PA, Schubauer-Berigan MK, Mayweather C, Geraci $\mathrm{CL}$, Zumwalde R, McKernan JL. Issues in the development of epidemiologic studies of workers exposed to engineered nanoparticles. J Occup Environ Med 2009 Mar;51(3):323- 
35. https://doi.org/10.1097/JOM.0b013e3181990c2c.

5. Riediker M, Schubauer-Berigan MK, Brouwer DH, Nelissen I, Koppen G, Frijns E et al. A road map toward a globally harmonized approach for occupational health surveillance and epidemiology in nanomaterial workers. J Occup Environ Med 2012 Oct;54(10):1214-23. https://doi. org/10.1097/JOM.0b013e31826e27f1.

6. Gazzano E, Ghiazza M, Polimeni M, Bolis V, Fenoglio I, Attanasio A et al. Physicochemical determinants in the cellular responses to nanostructured amorphous silicas. Toxicol Sci 2012 Jul;128(1):158-70. https://doi. org/10.1093/toxsci/kfs 128 .

7. World Health Organization. WHO Guidelines on protecting workers from potential risks of manufactured nanomaterials. Geneva, World Health Organization, 2017. Available from: http://apps.who.int/iris/bitstream/hand le/10665/259671/9789241550048-eng.pdf;jsessionid=6 7047D04C8A5DD24AF6A1036704F5713? sequence $=1$. Accessed on 31 July 2017.

8. Moher D, Liberati A, Tetzlaff J, Altman DG; PRISMA Group. Preferred reporting items for systematic reviews and meta-analyses: the PRISMA statement. PLoS Med 2009 Jul;6(7):e1000097. https://doi.org/10.1371/journal. pmed.1000097.

9. The Royal Society and The Royal Academy of Engineering. Nanoscience and nanotechnologies: opportunities and uncertainties. The Royal Society and The Royal Academy of Engineering, London, 2004. Available from: https:// royalsociety.org/ /media/Royal_Society_Content/policy/ publications/2004/9693.pdf. Accessed on 31 July 2018.

10. Liou SH, Tsai CS, Pelclova D, Schubauer-Berigan MK, Schulte PA. Assessing the first wave of epidemiological studies of nanomaterial workers. J Nanopart Res 2015 Oct;17:413. https://doi.org/10.1007/s11051-015-3219-7.

11. Bergamaschi E, Guseva-Canu I, Prina-Mello A, Magrini A. Biomonitoring. In B. Fadeel, A. Pietroiusti A, Shvedova A (Eds). Adverse effects of engineered nanomaterials, $2^{\text {nd }} \mathrm{Ed}$. London England: Academic Press; 2017. p. 225-60.

12. Gulumian M, Verbeek J, Andraos C, Sanabria N, de Jager P. Systematic review of screening and surveillance program to protect workers from nanomaterials. PLoS One 2016 Nov;11(11):e0166071. https://doi.org/10.1371/journal. pone. 0166071 .

13. Long CM, Nascarella MA, Valberg PA. Carbon black vs. black carbon and other airborne materials containing elemental carbon: physical and chemical distinctions. Environ Pollut 2013 Oct;181:271-86. https://doi. org/10.1016/j.envpol.2013.06.009.

14. International Agency for Research on Cancer (IARC). Carbon Black, Titanium Dioxide and Talc. Lyon. 2010; 93-97. Available from: https://monographs.iarc.fr/ENG/ Monographs/vol93/mono93-7.pdf.

15. Küpper HU, Breitstadt R, Ulmer WT. Effects on the lung function of exposure to carbon black dusts. Results of a study carried out on 677 members of staff of the DEGUSSA factory in Kalscheuren/Germany. Int Arch Occup Environ
Health 1996;68(6):478-83.

16. Gardiner $\mathrm{K}$, van Tongeren $\mathrm{M}$, Harrington M. Respiratory health effects from exposure to carbon black: results of the phase 2 and 3 cross sectional studies in the European carbon black manufacturing industry. Occup Environ Med 2001 Aug;58(8):496-503. https://doi.org/10.1136/oem.58.8.496.

17. van Tongeren MJ, Gardiner K, Rossiter CE, Beach J, Harber P, Harrington MJ. Longitudinal analyses of chest radiographs from the European Carbon Black Respiratory Morbidity Study. Eur Respir J 2002 Aug;20(2):417-25. https://doi.org/10.1183/09031936.02.00224502.

18. Harber P, Muranko H, Solis S, Torossian A, Merz B. Effect of carbon black exposure on respiratory function and symptoms. J Occup Environ Med 2003 Feb;45(2):144-55. https://doi.org/10.1097/01.jom.0000052955.59271.66.

19. Neghab M, Mohraz MH, Hassanzadeh J. Symptoms of respiratory disease and lung functional impairment associated with occupational inhalation exposure to carbon black dust. J Occup Health 2011;53(6):432-8. https://doi. org/10.1539/joh.11-0083-OA.

20. Zhang R, Dai Y, Zhang X, Niu Y, Meng T, Li Y et al. Reduced pulmonary function and increased proinflammatory cytokines in nanoscale carbon black-exposed workers. Part Fibre Toxicol 2014 Dec;11:73. https://doi. org/10.1186/s12989-014-0073-1.

21. Dai Y, Niu Y, Duan H, Bassig BA, Ye M, Zhang X et al. Effects of occupational exposure to carbon black on peripheral white blood cell counts and lymphocyte subsets. Environ Mol Mutagen 2016 Oct;57(8):615-22. https://doi. org/10.1002/em.22036.

22. Vesterdal LK, Folkmann JK, Jacobsen NR, Sheykhzade M, Wallin H, Loft S et al. Pulmonary exposure to carbon black nanoparticles and vascular effects. Part Fibre Toxicol 2010 Nov;7:33. https://doi.org/10.1186/1743-8977-7-33.

23. Gilmour PS, Ziesenis A, Morrison ER, Vickers MA, Drost EM, Ford I et al. Pulmonary and systemic effects of shortterm inhalation exposure to ultrafine carbon black particles. Toxicol Appl Pharmacol 2004 Feb;195(1):35-44. https://doi. org/10.1016/j.taap.2003.10.003.

24. Jackson P, Hougaard KS, Boisen AM, Jacobsen NR, Jensen KA, Møller P et al. Pulmonary exposure to carbon black by inhalation or instillation in pregnant mice: effects on liver DNA strand breaks in dams and offspring. Nanotoxicology 2012 Aug;6(5):486-500. https://doi.org/10.3109/17435390. 2011.587902 .

25. Li Y, Gao F, Xie Q, Niu Y, Meng T, Zhang R et al. [Study on the pulmonary inflammatory effects induced by inhalation exposure to nanoscale carbon black aerosol in mice]. Zhonghua Yu Fang Yi Xue Za Zhi 2014 Dec;48(12):1098103.

26. Santhanam P, Wagner JG, Elder A, Gelein R, Carter J, Driscoll K et al. Effects of subchronic inhalation exposure to carbon black nanoparticles in the nasal airways of laboratory rats. Int J Nanotechnol 2008;5:30-54. https://doi. org/10.1504/IJNT.2008.016712. 
27. Niwa Y, Hiura Y, Sawamura H, Iwai N. Inhalation exposure to carbon black induces inflammatory response in rats. Circ J 2008 Jan;72(1):144-9. https://doi.org/10.1253/circj.72.144.

28. Carter JM, Corson N, Driscoll KE, Elder A, Finkelstein JN, Harkema $\mathrm{JN}$ et al. A comparative dose-related response of several key pro- and antiinflammatory mediators in the lungs of rats, mice, and hamsters after subchronic inhalation of carbon black. J Occup Environ Med 2006 Dec;48(12):126578. https://doi.org/10.1097/01.jom.0000230489.06025.14.

29. Elder A, Gelein R, Finkelstein JN, Driscoll KE, Harkema J, Oberdörster G. Effects of subchronically inhaled carbon black in three species. I. Retention kinetics, lung inflammation, and histopathology. Toxicol Sci 2005 Dec;88(2):614-29. https://doi.org/10.1093/toxsci/kfi327.

30. Merget R, Bauer T, Küpper HU, Philippou S, Bauer HD, Breitstadt $\mathrm{R}$ et al. Health hazards due to the inhalation of amorphous silica. Arch Toxicol 2002 Jan;75(11-12):625-34. https://doi.org/10.1007/s002040100266.

31. Arts JH, Muijser H, Duistermaat E, Junker K, Kuper CF. Five-day inhalation toxicity study of three types of synthetic amorphous silicas in Wistar rats and postexposure evaluations for up to 3 months. Food Chem Toxicol 2007 Oct;45(10):1856-67. https://doi.org/10.1016/j. fct.2007.04.001.

32. van Kesteren PC, Cubadda F, Bouwmeester H, van Eijkeren JC, Dekkers S, de Jong WH et al. Novel insights into the risk assessment of the nanomaterial synthetic amorphous silica, additive E551, in food. Nanotoxicology 2015 May;9(4):44252. https://doi.org/10.3109/17435390.2014.940408.

33. McLaughlin JK, Chow WH, Levy LS. Amorphous silica: a review of health effects from inhalation exposure with particular reference to cancer. J Toxicol Environ Health 1997 Apr;50(6):553-66. https://doi. org/10.1080/15287399709532054.

34. Song $\mathrm{Y}, \mathrm{Li} \mathrm{X}, \mathrm{Du} \mathrm{X}$. Exposure to nanoparticles is related to pleural effusion, pulmonary fibrosis and granuloma. Eur Respir J 2009 Sep;34(3):559-67. https://doi. org/10.1183/09031936.00178308.

35. Song Y, Li X, Wang L, Rojanasakul Y, Castranova V, Li H et al. Nanomaterials in humans: identification, characteristics, and potential damage. Toxicol Pathol 2011 Aug;39(5):8419. https://doi.org/10.1177/0192623311413787.

36. Liao HY, Chung YT, Lai CH, Wang SL, Chiang HC, Li LA et al. Six-month follow-up study of health markers of nanomaterials among workers handling engineered nanomaterials. Nanotoxicology 2014 Aug;8 Suppl 1:100-10. https://doi.org/10.3109/17435390.2013.858793.

37. Liou SH, Tsou TC, Wang AL, Li LA, Chiang HC, Li WF et al. Epidemiological study of health hazards among workers handling engineered nanomaterials. J Nanopart Res 2012;14:878. https://doi.org/10.1007/s11051-012-0878-5.

38. Liou SH, Wu WT, Liao HY, Chen CY, Tsai CY, Jung WT et al. Global DNA methylation and oxidative stress biomarkers in workers exposed to metal oxide nanoparticles. J Hazard Mater 2017 Jun;331:329-35. https://doi.org/10.1016/j. jhazmat.2017.02.042.
39. Liou SH, Chen YC, Liao HY, Wang CJ, Chen JS, Lee HL. Increased levels of oxidative stress biomarkers in metal oxides nanomaterial-handling workers. Biomarkers 2016 Nov;21(7):600-6. https://doi.org/10.3109/135475 0X.2016.1160432.

40. Sutunkova MP, Solovyeva SN, Katsnelson BA, Gurvich VB, Privalova LI, Minigalieva IA et al. A paradoxical response of the rat organism to long-term inhalation of silica-containing submicron (predominantly nanoscale) particles of a collected industrial aerosol at realistic exposure levels. Toxicology 2017 Jun;384:59-68. https:// doi.org/10.1016/j.tox.2017.04.010.

41. Shin JH, Jeon K, Kim JK, Kim Y, Jo MS, Lee JS et al. Subacute inhalation toxicity study of synthetic amorphous silica nanoparticles in Sprague-Dawley rats. Inhal Toxicol 2017 Oct - Dec;29(12-14):567-76. https://doi.org/10.1080/ 08958378.2018 .1426661 .

42. Guichard Y, Maire MA, Sébillaud S, Fontana C, Langlais $\mathrm{C}$, Micillino JC et al. Genotoxicity of synthetic amorphous silica nanoparticles in rats following short-term exposure. Part 2: intratracheal instillation and intravenous injection. Environ Mol Mutagen 2015 Mar;56(2):228-44. https://doi. org/10.1002/em.21928.

43. Guttenberg M, Bezerra L, Neu-Baker NM, Del Pilar Sosa Idelchik M, Elder A, Oberdörster G et al. Biodistribution of inhaled metal oxide nanoparticles mimicking occupational exposure: a preliminary investigation using enhanced darkfield microscopy. J Biophotonics 2016 Oct;9(10):98793. https://doi.org/10.1002/jbio.201600125.

44. Katsnelson BA, Privalova LI, Sutunkova MP, Gurvich VB, Loginova NV, Minigalieva IA et al. Some inferences from in vivo experiments with metal and metal oxide nanoparticles: the pulmonary phagocytosis response, subchronic systemic toxicity and genotoxicity, regulatory proposals, searching for bioprotectors (a self-overview). Int J Nanomedicine 2015 Apr;10:3013-29. https://doi.org/10.2147/IJN.S80843.

45. Sun B, Pokhrel S, Dunphy DR, Zhang H, Ji Z, Wang X et al. Reduction of acute inflammatory effects of fumed silica nanoparticles in the ung by adjusting silanol display through calcination and metal doping. ACS Nano 2015 Sep;9(9):9357-72. https://doi.org/10.1021/ acsnano.5b03443.

46. Zhang H, Dunphy DR, Jiang X, Meng H, Sun B, Tarn D et al. Processing pathway dependence of amorphous silica nanoparticle toxicity: colloidal vs pyrolytic. J Am Chem Soc 2012 Sep;134(38):15790-804. https://doi.org/10.1021/ ja304907c.

47. Sandberg WJ, Låg M, Holme JA, Friede B, Gualtieri M, Kruszewski $\mathrm{M}$ et al. Comparison of non-crystalline silica nanoparticles in IL-1 $\beta$ release from macrophages. Part Fibre Toxicol 2012 Aug;9:32. https://doi.org/10.1186/1743-89779-32.

48. Taiwo OA, Sircar KD, Slade MD, Cantley LF, Vegso SJ, Rabinowitz PM et al. Incidence of asthma among aluminum workers. J Occup Environ Med 2006 Mar;48(3):275-82. https://doi.org/10.1097/01.jom.0000197876.31901.f5. 
49. Jederlinic PJ, Abraham JL, Churg A, Himmelstein JS, Epler GR, Gaensler EA. Pulmonary fibrosis in aluminum oxide workers. Investigation of nine workers, with pathologic examination and microanalysis in three of them. Am Rev Respir Dis 1990 Nov;142(5):1179-84. https://doi. org/10.1164/ajrccm/142.5.1179.

50. Kraus T, Schaller KH, Angerer J, Hilgers RD, Letzel S. Aluminosis--detection of an almost forgotten disease with HRCT. J Occup Med Toxicol 2006 Feb;1:4. https://doi. org/10.1186/1745-6673-1-4.

51. Björ O, Damber L, Edström C, Nilsson T. Long-term followup study of mortality and the incidence of cancer in a cohort of workers at a primary aluminum smelter in Sweden. Scand J Work Environ Health 2008 Dec;34(6):463-70. https://doi. org/10.5271/sjweh.1293.

52. Mazzoli-Rocha F, Dos Santos AN, Fernandes S, Ferreira Normando VM, Malm O, Nascimento Saldiva PH et al. Pulmonary function and histological impairment in mice after acute exposure to aluminum dust. Inhal Toxicol 2010 Aug;22(10):861-7. https://doi.org/10.3109/08958378.2010. 489074.

53. Thomassen Y, Koch W, Dunkhorst W, Ellingsen DG, Skaugset NP, Jordbekken L et al. Ultrafine particles at workplaces of a primary aluminium smelter. J Environ Monit 2006 Jan;8(1):127-33. https://doi.org/10.1039/ B514939H.

54. Rajsekhar PV, Selvam G, Goparaju A, Murthy BP, Reddy EN. Pulmonary responses of manufactured ultrafine aluminum oxide particles upon repeated exposure by inhalation in rats. Ind J For Med Tox. 2014;8:97-102. https://doi.org/10.5958/j.0973-9130.8.1.021.

55. Adamcakova-Dodd A, Stebounova LV, O'Shaughnessy PT, Kim JS, Grassian VH, Thorne PS. Murine pulmonary responses after sub-chronic exposure to aluminum oxidebased nanowhiskers. Part Fibre Toxicol 2012 Jun;9:22. https://doi.org/10.1186/1743-8977-9-22.

56. Park EJ, Lee SJ, Lee GH, Kim DW, Yoon C, Lee BS et al. Comparison of subchronic immunotoxicity of four different types of aluminum-based nanoparticles. J Appl Toxicol 2018 Apr;38(4):575-84. https://doi.org/10.1002/jat.3564.

57. Geetha P, Sarita P, Rao DK. Synthesis, properties and application of barium titanate nanoparticles. Int J Adv Tech Eng Sii 2016;4:1.

58. Genchi GG, Marino A, Rocca A, Mattoli V, Ciofani G. Barium titanate nanoparticles: promising multitasking vectors in nanomedicine. Nanotechnology 2016 Jun;27(23):232001. https://doi.org/10.1088/0957-4484/27/23/232001.

59. Dubey AK, Thrivikraman G, Basu B. Absence of systemic toxicity in mouse model towards $\mathrm{BaTiO}_{3}$ nanoparticulate based eluate treatment. J Mater Sci Mater Med 2015 Feb;26(2):103. https://doi.org/10.1007/s10856-015-5414-6.

60. Chen JL, Fayerweather WE. Epidemiologic study of workers exposed to titanium dioxide. J Occup Med 1988 Dec;30(12):937-42. https://doi.org/10.1097/00043764198812000-00011.
61. Boffetta P, Soutar A, Cherrie JW, Granath F, Andersen A, Anttila A et al. Mortality among workers employed in the titanium dioxide production industry in Europe. Cancer Causes Control 2004 Sep;15(7):697-706. https://doi. org/10.1023/B:CACO.0000036188.23970.22.

62. Heinrich U, Fuhst R, Rittinghausen R, Creutzenberg O, Bellmann B, Koch W et al. Chronic inhalation exposure of Wistar rats and two different strains of mice to diesel exhaust, carbon black and titanium dioxide. Inhal Toxicol 1995;7:533-56. https://doi. org/10.3109/08958379509015211.

63. Lee KP, Trochimowicz HJ, Reinhardt CF. Pulmonary response of rats exposed to titanium dioxide $\left(\mathrm{TiO}_{2}\right)$ by inhalation for two years. Toxicol Appl Pharmacol 1985 Jun;79(2):179-92. https://doi.org/10.1016/0041008X(85)90339-4.

64. Pelclova D, Barosova H, Kukutschova J, Zdimal V, Navratil $T$, Fenclova $Z$ et al. Raman microspectroscopy of exhaled breath condensate and urine in workers exposed to fine and nano $\mathrm{TiO}_{2}$ particles: a cross-sectional study. J Breath Res 2015 Jul;9(3):036008. https://doi.org/10.1088/1752$7155 / 9 / 3 / 036008$.

65. Zhao L, Zhu Y, Chen Z, Xu H, Zhou J, Tang S et al. Cardiopulmonary effects induced by occupational exposure to titanium dioxide nanoparticles. Nanotoxicology 2018 Mar;12(2):169-84. https://doi.org/10.1080/17435390.2018 .1425502 .

66. Wu WT, Liao HY, Chung YT, Li WF, Tsou TC, Li LA et al. Effect of nanoparticles exposure on fractional exhaled nitric oxide (FENO) in workers exposed to nanomaterials. Int $\mathrm{J}$ Mol Sci 2014 Jan;15(1):878-94. https://doi.org/10.3390/ ijms15010878.

67. Pelclova D, Zdimal V, Kacer P, Fenclova Z, Vlckova S, Komarc $\mathrm{M}$ et al. Leukotrienes in exhaled breath condensate and fractional exhaled nitric oxide in workers exposed to $\mathrm{TiO}_{2}$ nanoparticles. J Breath Res 2016 Jun;10(3):036004. https://doi.org/10.1088/1752-7155/10/3/036004.

68. Ichihara S, Li W, Omura S, Fujitani Y, Liu Y, Wang Q et al. Exposure assessment and heart rate variability monitoring in workers handling titanium dioxide particles: a pilot study. J Nanopart Res 2016;18:1-14. https://doi.org/10.1007/ s11051-016-3340-2.

69. Pelclova D, Zdimal V, Fenclova Z, Vlckova S, Turci F, Corazzari I et al. Markers of oxidative damage of nucleic acids and proteins among workers exposed to $\mathrm{TiO}_{2}$ (nano) particles. Occup Environ Med 2016 Feb;73(2):110-8. https://doi.org/10.1136/oemed-2015-103161.

70. Pelclova D, Zdimal V, Kacer P, Zikova N, Komarc M, Fenclova $\mathrm{Z}$ et al. Markers of lipid oxidative damage in the exhaled breath condensate of nano $\mathrm{TiO}_{2}$ production workers. Nanotoxicology 2017 Feb;11(1):52-63. https://doi.org/10.10 80/17435390.2016.1262921.

71. Pelclova D, Zdimal V, Kacer P, Komarc M, Fenclova $\mathrm{Z}$, Vlckova $\mathrm{S}$ et al. Markers of lipid oxidative damage among office workers exposed intermittently to air pollutants including nanoTiO ${ }_{2}$ particles. Rev Environ 
Health 2017 Mar;32(1-2):193-200. https://doi.org/10.1515/ reveh-2016-0030.

72. Oyabu T, Myojo T, Lee BW, Okada T, Izumi H, Yoshiura $\mathrm{Y}$ et al. Biopersistence of $\mathrm{NiO}$ and $\mathrm{TiO}_{2}$ Nanoparticles Following Intratracheal Instillation and Inhalation. Int $\mathrm{J}$ Mol Sci 2017 Dec;18(12):E2757. https://doi.org/10.3390/ ijms 18122757 .

73. Koivisto AJ, Makinen M, Rossi EM, Lindberg HK, Miettinen M, Falck GC et al. Aerosol characterization and lung deposition of synthesized $\mathrm{TiO}_{2}$ nanoparticles for murine inhalation studies. J Nanopart Res 2011;13:2949-61. https://doi.org/10.1007/s11051-010-0186-x.

74. Geiser M, Rothen-Rutishauser B, Kapp N, Schürch S, Kreyling W, Schulz $\mathrm{H}$ et al. Ultrafine particles cross cellular membranes by nonphagocytic mechanisms in lungs and in cultured cells. Environ Health Perspect 2005 Nov;113(11):1555-60. https://doi.org/10.1289/ehp.8006.

75. van Ravenzwaay B, Landsiedel R, Fabian E, Burkhardt S, Strauss V, Ma-Hock L. Comparing fate and effects of three particles of different surface properties: nano- $\mathrm{TiO}_{2}$, pigmentary $\mathrm{TiO}_{2}$ and quartz. Toxicol Lett 2009 May;186(3):152-9. https://doi.org/10.1016/j. toxlet.2008.11.020.

76. Rossi EM, Pylkkänen L, Koivisto AJ, Vippola M, Jensen $\mathrm{KA}$, Miettinen $\mathrm{M}$ et al. Airway exposure to silica-coated $\mathrm{TiO}_{2}$ nanoparticles induces pulmonary neutrophilia in mice. Toxicol Sci 2010 Feb;113(2):422-33. https://doi. org/10.1093/toxsci/kfp254.

77. Rossi EM, Pylkkänen L, Koivisto AJ, Nykäsenoja H, Wolff $\mathrm{H}$, Savolainen $\mathrm{K}$ et al. Inhalation exposure to nanosized and fine $\mathrm{TiO}_{2}$ particles inhibits features of allergic asthma in a murine model. Part Fibre Toxicol 2010 Nov; 7:35. https://doi. org/10.1186/1743-8977-7-35.

78. Yu KN, Sung JH, Lee S, Kim JE, Kim S, Cho WY et al. Inhalation of titanium dioxide induces endoplasmic reticulum stress-mediated autophagy and inflammation in mice. Food Chem Toxicol 2015 Nov;85:106-13. https://doi. org/10.1016/j.fct.2015.08.001.

79. Ma-Hock L, Burkhardt S, Strauss V, Gamer AO, Wiench $\mathrm{K}$, van Ravenzwaay B et al. Development of a short-term inhalation test in the rat using nano-titanium dioxide as a model substance. Inhal Toxicol 2009 Feb;21(2):102-18. https://doi.org/10.1080/08958370802361057.

80. Hougaard KS, Jackson P, Jensen KA, Sloth JJ, Löschner $\mathrm{K}$, Larsen $\mathrm{EH}$ et al. Effects of prenatal exposure to surfacecoated nanosized titanium dioxide (UV-Titan). A study in mice. Part Fibre Toxicol 2010 Jun;7:16. https://doi. org/10.1186/1743-8977-7-16.

81. Iavicoli I, Leso V, Bergamaschi A. Toxicological effects of titanium dioxide nanoparticles: a review of in vivo studies. J Nanomaterials. 2012;Article ID 964381, 36 pages.

82. National Institute for Occupational Safety and Health (NIOSH). Occupational exposure to titanium dioxide. Centers for Disease Control and Prevention, US Department of Health and Human Services (DHHS). Current Intelligence Bulletin 63:2012;2011-160. https://www.cdc.gov/niosh/docs/2011- 160/pdfs/2011-160.pdf.

83. Scuri M, Chen BT, Castranova V, Reynolds JS, Johnson VJ, Samsell L et al. Effects of titanium dioxide nanoparticle exposure on neuroimmune responses in rat airways. $\mathrm{J}$ Toxicol Environ Health A 2010;73(20):1353-69. https://doi. org/10.1080/15287394.2010.497436.

84. Leppänen M, Korpi A, Miettinen M, Leskinen J, Torvela T, Rossi EM et al. Nanosized $\mathrm{TiO}_{2}$ caused minor airflow limitation in the murine airways. Arch Toxicol 2011 Jul;85(7):827-39. https://doi.org/10.1007/s00204-0110644-y.

85. Baisch BL, Corson NM, Wade-Mercer P, Gelein R, Kennell AJ, Oberdörster $G$ et al. Equivalent titanium dioxide nanoparticle deposition by intratracheal instillation and whole body inhalation: the effect of dose rate on acute respiratory tract inflammation. Part Fibre Toxicol 2014 Jan;11:5. https://doi.org/10.1186/1743-8977-11-5.

86. Grassian VH, O'shaughnessy PT, Adamcakova-Dodd A, Pettibone JM, Thorne PS. Inhalation exposure study of titanium dioxide nanoparticles with a primary particle size of 2 to $5 \mathrm{~nm}$. Environ Health Perspect 2007 Mar;115(3):397402. https://doi.org/10.1289/ehp.9469.

87. Kan H, Wu Z, Young SH, Chen TH, Cumpston JL, Chen $F$ et al. Pulmonary exposure of rats to ultrafine titanium dioxide enhances cardiac protein phosphorylation and substance $\mathrm{P}$ synthesis in nodose ganglia. Nanotoxicology 2012 Nov;6(7):736-45. https://doi.org/10.3109/17435390.2 011.611915 .

88. Nurkiewicz TR, Porter DW, Hubbs AF, Cumpston JL, Chen BT, Frazer DG et al. Nanoparticle inhalation augments particle-dependent systemic microvascular dysfunction. Part Fibre Toxicol 2008 Feb;5:1. https://doi.org/10.1186/17438977-5-1.

89. LeBlanc AJ, Moseley AM, Chen BT, Frazer D, Castranova V, Nurkiewicz TR. Nanoparticle inhalation impairs coronary microvascular reactivity via a local reactive oxygen species-dependent mechanism. Cardiovasc Toxicol 2010 Mar;10(1):27-36. https://doi.org/10.1007/s12012-0099060-4.

90. LeBlanc AJ, Cumpston JL, Chen BT, Frazer D, Castranova V, Nurkiewicz TR. Nanoparticle inhalation impairs endothelium-dependent vasodilation in subepicardial arterioles. J Toxicol Environ Health A 2009;72(24):157684. https://doi.org/10.1080/15287390903232467.

91. Stapleton PA, Nichols CE, Yi J, McBride CR, Minarchick VC, Shepherd DL et al. Microvascular and mitochondrial dysfunction in the female F1 generation after gestational $\mathrm{TiO}_{2}$ nanoparticle exposure. Nanotoxicology 2015;9(8):94151. https://doi.org/10.3109/17435390.2014.984251.

92. Nurkiewicz TR, Porter DW, Hubbs AF, Stone S, Chen BT, Frazer DG et al. Pulmonary nanoparticle exposure disrupts systemic microvascular nitric oxide signaling. Toxicol Sci 2009 Jul;110(1):191-203. https://doi.org/10.1093/toxsci/ kfp051.

93. Halcox JP, Roy C, Tubach F, Banegas JR, Dallongeville 
J, De Backer G et al. C-reactive protein levels in patients at cardiovascular risk: EURIKA study. BMC Cardiovasc Disord 2014 Feb;14:25. https://doi.org/10.1186/1471-226114-25.

94. Lawrence NJ, Brewer JR, Wang L, Wu TS, Wells-Kingsbury $\mathrm{J}$, Ihrig MM et al. Defect engineering in cubic cerium oxide nanostructures for catalytic oxidation. Nano Lett 2011 Jul;11(7):2666-71. https://doi.org/10.1021/n1200722z.

95. Dao NN, Luu MD, Nguyen QK, Kim BS. UV absorption by cerium oxide nanoparticles/epoxy composite thin films. Adv. Nat. Sci. Nanosci. Nanotechnol. 2011;2:045013.

96. Ma J, Mercer RR, Barger M, Schwegler-Berry D, Cohen JM, Demokritou P et al. Effects of amorphous silica coating on cerium oxide nanoparticles induced pulmonary responses. Toxicol Appl Pharmacol 2015 Oct;288(1):63-73. https://doi. org/10.1016/j.taap.2015.07.012.

97. Aalapati S, Ganapathy S, Manapuram S, Anumolu G, Prakya BM. Toxicity and bio-accumulation of inhaled cerium oxide nanoparticles in CD1 mice. Nanotoxicology 2014 Nov;8(7):786-98.

98. Morimoto Y, Izumi H, Yoshiura Y, Tomonaga T, Oyabu T, Myojo T et al. Pulmonary toxicity of well-dispersed cerium oxide nanoparticles following intratracheal instillation and inhalation. J Nanopart Res 2015;17(11):442. https://doi. org/10.1007/s11051-015-3249-1.

99. Srinivas A, Rao PJ, Selvam G, Murthy PB, Reddy PN. Acute inhalation toxicity of cerium oxide nanoparticles in rats. Toxicol Lett 2011 Aug;205(2):105-15. https://doi. org/10.1016/j.toxlet.2011.05.1027.

100. Schwotzer D, Ernst H, Schaudien D, Kock H, Pohlmann G, Dasenbrock C et al. Effects from a 90-day inhalation toxicity study with cerium oxide and barium sulfate nanoparticles in rats. Part Fibre Toxicol 2017 Jul;14(1):23. https://doi. org/10.1186/s12989-017-0204-6.

101. Geraets L, Oomen AG, Schroeter JD, Coleman VA, Cassee FR. Tissue distribution of inhaled micro- and nano-sized cerium oxide particles in rats: results from a 28-day exposure study. oxicol Sci. 2012;127:463-473.

102. Demokritou P, Gass S, Pyrgiotakis G, Cohen JM, Goldsmith $\mathrm{W}$, McKinney $\mathrm{W}$ et al. An in vivo and in vitro toxicological characterisation of realistic nanoscale $\mathrm{CeO}_{2}$ inhalation exposures. Nanotoxicology 2013 Dec;7(8):1338-50. https:// doi.org/10.3109/17435390.2012.739665.

103. Cordelli E, Keller J, Eleuteri P, Villani P, Ma-Hock L, Schulz $\mathrm{M}$ et al. No genotoxicity in rat blood cells upon 3- or 6-month inhalation exposure to $\mathrm{CeO}_{2}$ or $\mathrm{BaSO}_{4}$ nanomaterials. Mutagenesis 2017 Jan;32(1):13-22. https:// doi.org/10.1093/mutage/gew005.

104. Antonini JM. Health effects of welding. Crit Rev Toxicol 2003;33(1):61-103. https://doi.org/10.1080/713611032.

105. Sferlazza SJ, Beckett WS. The respiratory health of welders. Am Rev Respir Dis 1991 May;143(5 Pt 1):1134-48. https:// doi.org/10.1164/ajrccm/143.5_Pt_1.1134.

106. Donaldson K, Tran L, Jimenez LA, Duffin R, Newby DE, Mills $\mathrm{N}$ et al. Combustion-derived nanoparticles: a review of their toxicology following inhalation exposure. Part Fibre Toxicol 2005 Oct;2:10. https://doi.org/10.1186/1743-89772-10.

107. Lai Cy-Y. Lai C-H, Chuang H-C, Pan C-H, Yen C-C, Lin W-Y, Chen J-K, Lin L-Y, Chuang K-J. Physicochemistry and cardiovascular toxicity of metal fume PM 2.5: a study of human coronary artery end of the lial cells and welding workers. Sci Rep 2016;6:33515. https://doi.org/10.1038/ srep33515.

108. Cavallari JM, Eisen EA, Chen JC, Fang SC, Dobson CB, Schwartz $\mathrm{J}$ et al. Night heart rate variability and particulate exposures among boilermaker construction workers. Environ Health Perspect 2007 Jul;115(7):1046-51. https:// doi.org/10.1289/ehp.10019.

109. Chinn DJ, Stevenson IC, Cotes JE. Longitudinal respiratory survey of shipyard workers: effects of trade and atopic status. Br J Ind Med 1990 Feb;47(2):83-90.

110. Gordon T, Chen LC, Fine JM, Schlesinger RB, Su WY, Kimmel TA et al. Pulmonary effects of inhaled zinc oxide in human subjects, guinea pigs, rats, and rabbits. Am Ind Hyg Assoc J 1992 Aug;53(8):503-9. https://doi. org/10.1080/15298669291360030.

111. Monsé C, Hagemeyer O, Raulf M, Jettkant B, van Kampen V, Kendzia B et al. Concentration-dependent systemic response after inhalation of nano-sized zinc oxide particles in human volunteers. Part Fibre Toxicol 2018 Feb;15(1):8. https://doi.org/10.1186/s12989-018-0246-4.

112. Chuang HC, Juan HT, Chang CN, Yan YH, Yuan TH, Wang JS et al. Cardiopulmonary toxicity of pulmonary exposure to occupationally relevant zinc oxide nanoparticles. Nanotoxicology 2014 Sep;8(6):593-604. https://doi.org/10 $.3109 / 17435390.2013 .809809$.

113. Ho M, Wu KY, Chein HM, Chen LC, Cheng TJ. Pulmonary toxicity of inhaled nanoscale and fine zinc oxide particles: mass and surface area as an exposure metric. Inhal Toxicol 2011 Dec;23(14):947-56. https://doi.org/10.3109/0895837 8.2011 .629235

114. Morimoto Y, Izumi H, Yoshiura Y, Tomonaga T, Oyabu T, Myojo T et al. Evaluation of pulmonary toxicity of zinc oxide nanoparticles following inhalation and intratracheal instillation. Int J Mol Sci 2016 Aug;17(8):E1241. https://doi. org/10.3390/ijms 17081241 .

115. Adamcakova-Dodd A, Stebounova LV, Kim JS, Vorrink SU, Ault AP, O'Shaughnessy PT et al. Toxicity assessment of zinc oxide nanoparticles using sub-acute and subchronic murine inhalation models. Part Fibre Toxicol 2014 Apr;11:15. https://doi.org/10.1186/1743-8977-11-15.

116. Jain S, Rachamalla M, Kulkarnic A, Kaur J. Tikook. Pulmonary fibrotic response to inhalation of $\mathrm{ZnO}$ and toluene co-exposure through direct flow hose only chamber. Inhal Toxicol 2013;25:703-13. https://doi.org/10.3109/0895 8378.2013.839765.

117. Schubauer-Berigan MK, Dahm MM, Erdely A, Beard JD, Eileen Birch M, Evans DE et al. Association of pulmonary, cardiovascular, and hematologic metrics with carbon nanotube and nanofiber exposure among U.S. workers: a 
cross-sectional study. Part Fibre Toxicol 2018 May;15(1):22. https://doi.org/10.1186/s12989-018-0258-0.

118. Zuo L, Otenbaker NP, Rose BA, Salisbury KS. Molecular mechanisms of reactive oxygen species-related pulmonary inflammation and asthma. Mol Immunol 2013 Nov;56(12):57-63. https://doi.org/10.1016/j.molimm.2013.04.002.

119. MacNee W. Oxidative stress and lung inflammation in airways disease. Eur J Pharmacol 2001 Oct;429(1-3):195207. https://doi.org/10.1016/S0014-2999(01)01320-6.

120. Dong J, Ma Q. Advances in mechanisms and signaling pathways of carbon nanotube toxicity. Nanotoxicology 2015;9(5):658-76. https://doi.org/10.3109/17435390.2015. 1009187.

121. Lee JS, Choi YC, Shin JH, Lee JH, Lee Y, Park SY et al. Health surveillance study of workers who manufacture multi-walled carbon nanotubes. Nanotoxicology 2015;9(6):802-11. https://doi.org/10.3109/17435390.2014. 978404.

122. Vlaanderen J, Pronk A, Rothman N, Hildesheim A, Silverman D, Hosgood HD et al. A cross-sectional study of changes in markers of immunological effects and lung health due to exposure to multi-walled carbon nanotubes. Nanotoxicology 2017 Apr;11(3):395-404. https://doi.org/1 0.1080/17435390.2017.1308031.

123. Fatkhutdinova LM, Khaliullin TO, Vasil'yeva OL, Zalyalov RR, Mustafin IG, Kisin ER et al. Fibrosis biomarkers in workers exposed to MWCNTs. Toxicol Appl Pharmacol 2016 May;299:125-31. https://doi.org/10.1016/j. taap.2016.02.016.

124. Beard JD, Erdely A, Dahm MM, de Perio MA, Birch ME, Evans DE et al. Carbon nanotube and nanofiber exposure and sputum and blood biomarkers of early effect among U.S. workers. Environ Int 2018 Jul;116:214-28. https://doi. org/10.1016/j.envint.2018.04.004.

125. Kuijpers E, Pronk A, Kleemann R, Vlaanderen J, Lan Q, Rothman $\mathrm{N}$ et al. Cardiovascular effects among workers exposed to multiwalled carbon nanotubes. Occup Environ Med 2018 May;75(5):351-8. https://doi.org/10.1136/ oemed-2017-104796.

126. International Agency for research on Cancer (IARC). Working Group on the Evaluation of Carcinogenic Risks to Humans. Some nanomaterials and some fibres. Vol 111, Lyons, France, 2014. Available from: https://monographs.iarc.fr/wpcontent/uploads/2018/06/mono111.pdf. Accessed on 31 July 2018.

127. Shvedova AA, Yanamala N, Kisin ER, Khailullin TO, Birch ME, Fatkhutdinova LM. Integrated analysis of dysregulated ncRNA and mRNA expression profiles in humans exposed to carbon nanotubes. PLoS One 2016 Mar;11(3):e0150628. https://doi.org/10.1371/journal.pone.0150628.

128. Ghosh M, Öner D, Poels K, Tabish AM, Vlaanderen J, Pronk A et al. Changes in DNA methylation induced by multi-walled carbon nanotube exposure in the workplace. Nanotoxicology 2017 Nov - Dec;11(9-10):1195-210. https://doi.org/10.1080/17435390.2017.1406169.
129. National Institute for Occupational Safety and Health (NIOSH). Occupational exposure to carbon nanotubes and nanofibers. US Department of Health and Human Services (DHHS), Centers for Disease Control and Prevention, Cincinnati. Current Intelligence Bulletin 65:2013;145. https:// www.cdc.gov/niosh/docs/2013-145/pdfs/2013-145.pdf

130. Mercer RR, Scabilloni JF, Hubbs AF, Wang L, Battelli LA, McKinney W et al. Extrapulmonary transport of MWCNT following inhalation exposure. Part Fibre Toxicol 2013 Aug;10:38. https://doi.org/10.1186/1743-8977-10-38.

131. Pauluhn J. Subchronic 13-week inhalation exposure of rats to multiwalled carbon nanotubes: toxic effects are determined by density of agglomerate structures, not fibrillar structures. Toxicol Sci 2010 Jan;113(1):226-42. https://doi. org/10.1093/toxsci/kfp247.

132. Morimoto Y, Hirohashi M, Ogami A, Oyabu T, Myojo T, Todoroki $\mathrm{M}$ et al. Pulmonary toxicity of well-dispersed multi-wall carbon nanotubes following inhalation and intratracheal instillation. Nanotoxicology 2012 Sep;6(6):587-99. https://doi.org/10.3109/17435390.2011.5 94912.

133. Ryman-Rasmussen JP, Cesta MF, Brody AR, ShipleyPhillips JK, Everitt JI, Tewksbury EW et al. Inhaled carbon nanotubes reach the subpleural tissue in mice. Nat Nanotechnol 2009 Nov;4(11):747-51. https://doi. org/10.1038/nnano.2009.305.

134. Shvedova AA, Kisin E, Murray AR, Johnson VJ, Gorelik $\mathrm{O}$, Arepalli $\mathrm{S}$ et al. Inhalation vs. aspiration of single-walled carbon nanotubes in C57BL/6 mice: inflammation, fibrosis, oxidative stress, and mutagenesis. Am J Physiol Lung Cell Mol Physiol 2008 Oct;295(4):L552-65. https://doi. org/10.1152/ajplung.90287.2008.

135. Ma-Hock L, Treumann S, Strauss V, Brill S, Luizi F, Mertler $M$ et al. Inhalation toxicity of multiwall carbon nanotubes in rats exposed for 3 months. Toxicol Sci 2009 Dec;112(2):468-81. https://doi.org/10.1093/toxsci/kfp146.

136. Delorme MP, Muro Y, Arai T, Banas DA, Frame SR, Reed KL et al. Ninety-day inhalation toxicity study with a vapor grown carbon nanofiber in rats. Toxicol Sci 2012 Aug;128(2):449-60. https://doi.org/10.1093/toxsci/kfs172.

137. Umeda Y, Kasai T, Saito M, Kondo H, Toya T, Aiso S et al. Two-week Toxicity of Multi-walled Carbon Nanotubes by Whole-body Inhalation Exposure in Rats. J Toxicol Pathol 2013 Jun;26(2):131-40. https://doi.org/10.1293/tox.26.131.

138. Kasai T, Gotoh K, Nishizawa T, Sasaki T, Katagiri T, Umeda $\mathrm{Y}$ et al. Development of a new multi-walled carbon nanotube (MWCNT) aerosol generation and exposure system and confirmation of suitability for conducting a single-exposure inhalation study of MWCNT in rats. Nanotoxicology 2014 Mar;8(2):169-78. https://doi.org/10. 3109/17435390.2013.766277.

139. Pauluhn J, Rosenbruch M. Lung burdens and kinetics of multi-walled carbon nanotubes (Baytubes) are highly dependent on the disaggregation of aerosolized MWCNT. Nanotoxicology 2015 Mar;9(2):242-52. https://doi.org/10. $3109 / 17435390.2014 .918204$. 
140. Treumann S, Ma-Hock L, Gröters S, Landsiedel R, van Ravenzwaay B. Additional histopathologic examination of the lungs from a 3-month inhalation toxicity study with multiwall carbon nanotubes in rats. Toxicol Sci 2013 Jul;134(1):103-10. https://doi.org/10.1093/toxsci/kft089.

141. Kido T, Tsunoda M, Kasai T, Sasaki T, Umeda Y, Senoh $\mathrm{H}$ et al. The increases in relative mRNA expressions of inflammatory cytokines and chemokines in splenic macrophages from rats exposed to multi-walled carbon nanotubes by whole-body inhalation for 13 weeks. Inhal Toxicol 2014 Oct;26(12):750-8. https://doi.org/10.3109/08 958378.2014.953275.

142. Kim JS, Sung JH, Choi BG, Ryu HY, Song KS, Shin JH et al. In vivo genotoxicity evaluation of lung cells from Fischer 344 rats following 28 days of inhalation exposure to MWCNTs, plus 28 days and 90 days post-exposure. Inhal Toxicol 2014 Mar;26(4):222-34. https://doi.org/10.3109/08 958378.2013.878006.

143. Stapleton PA, Minarchick VC, Cumpston AM, McKinney W, Chen BT, Sager TM et al. Impairment of coronary arteriolar endothelium-dependent dilation after multi-walled carbon nanotube inhalation: a time-course study. Int J Mol Sci 2012 Oct;13(11):13781-803. https://doi.org/10.3390/ ijms 131113781 .

144. Mitchell LA, Gao J, Wal RV, Gigliotti A, Burchiel SW, McDonald JD. Pulmonary and systemic immune response to inhaled multiwalled carbon nanotubes. Toxicol Sci 2007 Nov;100(1):203-14. https://doi.org/10.1093/toxsci/kfm196.

145. Sargent LM, Porter DW, Staska LM, Hubbs AF, Lowry DT, Battelli L et al. Promotion of lung adenocarcinoma following inhalation exposure to multi-walled carbon nanotubes. Part Fibre Toxicol 2014 Jan;11:3. https://doi. org/10.1186/1743-8977-11-3.

146. Wijnhoven SW, Peijnenburg W, Herbert CA, Hagens WI, Oomen AG, Heugens $\mathrm{CH}$ et al. Nano-silver-a review of available data and knowledge gaps in human and environmental risk assessment. Nanotoxicology 2009;3:10938. https://doi.org/10.1080/17435390902725914.

147. Lee JH, Kwon M, Ji JH, Kang CS, Ahn KH, Han JH et al. Exposure assessment of workplaces manufacturing nanosized $\mathrm{TiO}_{2}$ and silver. Inhal Toxicol $2011 \mathrm{Mar}$;23(4):22636. https://doi.org/10.3109/08958378.2011.562567.

148. Lee JH, Mun J, Park JD, Yu IJ. A health surveillance case study on workers who manufacture silver nanomaterials. Nanotoxicology 2012 Sep;6(6):667-9. https://doi.org/10.31 09/17435390.2011.600840.

149. Anderson DS, Patchin ES, Silva RM, Uyeminami DL, Sharmah A, Guo $\mathrm{T}$ et al. Influence of particle size on persistence and clearance of aerosolized silver nanoparticles in the rat lung. Toxicol Sci 2015 Apr;144(2):366-81. https:// doi.org/10.1093/toxsci/kfv005.

150. Seiffert J, Buckley A, Leo B, Martin NG, Zhu J, Dai R et al. Pulmonary effects of inhalation of spark-generated silver nanoparticles in Brown-Norway and Sprague-Dawley rats. Respir Res 2016 Jul;17(1):85. https://doi.org/10.1186/ s12931-016-0407-7.
151. Stebounova LV, Adamcakova-Dodd A, Kim JS, Park H, O'Shaughnessy PT, Grassian VH et al. Nanosilver induces minimal lung toxicity or inflammation in a subacute murine inhalation model. Part Fibre Toxicol 2011 Jan;8(1):5. https://doi.org/10.1186/1743-8977-8-5.

152. Braakhuis HM, Gosens I, Krystek P, Boere JA, Cassee FR, Fokkens PH et al. Particle size dependent deposition and pulmonary inflammation after short-term inhalation of silver nanoparticles. Part Fibre Toxicol 2014 Sep;11:49. https://doi. org/10.1186/s12989-014-0049-1.

153. Braakhuis HM, Cassee FR, Fokkens PH, de la Fonteyne LJ, Oomen AG, Krystek P et al. Identification of the appropriate dose metric for pulmonary inflammation of silver nanoparticles in an inhalation toxicity study. Nanotoxicology 2016;10(1):63-73.

154. Silva RM, Anderson DS, Peake J, Edwards PC, Patchin ES, Guo $T$ et al. Aerosolized silver nanoparticles in the rat lung and pulmonary responses over time. Toxicol Pathol 2016 Jul;44(5):673-86. https://doi. org/10.1177/0192623316629804.

155. Song KS, Sung JH, Ji JH, Lee JH, Lee JS, Ryu HR et al. Recovery from silver-nanoparticle-exposure-induced lung inflammation and lung function changes in Sprague Dawley rats. Nanotoxicology 2013 Mar;7(2):169-80. https://doi.org/ 10.3109/17435390.2011.648223.

156. Hyun JS, Lee BS, Ryu HY, Sung JH, Chung KH, Yu IJ. Effects of repeated silver nanoparticles exposure on the histological structure and mucins of nasal respiratory mucosa in rats. Toxicol Lett 2008 Nov; 182(1-3):24-8. https://doi.org/10.1016/j.toxlet.2008.08.003.

157. Cho HS, Sung JH, Song KS, Kim JS, Ji JH, Lee JH et al. Genotoxicity of silver nanoparticles in lung cells of Sprague Dawley Rats after 12 weeks of inhalation exposure. Toxics 2013;1:36-45. https://doi.org/10.3390/toxics 1010036 .

158. Sung JH, Ji JH, Park JD, Yoon JU, Kim DS, Jeon KS et al. Subchronic inhalation toxicity of silver nanoparticles. Toxicol Sci 2009 Apr;108(2):452-61. https:// doi.org/10.1093/toxsci/kfn246.

159. Sung JH, Ji JH, Yoon JU, Kim DS, Song MY, Jeong $J$ et al. Lung function changes in Sprague-Dawley rats after prolonged inhalation exposure to silver nanoparticles. Inhal Toxicol 2008 Apr;20(6):567-74. https:// doi.org/10.1080/08958370701874671.

160. Su CL, Chen TT, Chang CC, Chuang KJ, Wu CK, Liu WT et al. Taiwan CardioPulmonary Research Group (T-CPR). Comparative proteomics of inhaled silver nanoparticles in healthy and allergen provoked mice. Int $\mathrm{J}$ Nanomedicine 2013;8:2783-99.

161.Ji JH, Jung JH, Kim SS, Yoon JU, Park JD, Choi BS et al. Twenty-eight-day inhalation toxicity study of silver nanoparticles in Sprague-Dawley rats. Inhal Toxicol 2007 Aug;19(10):857-71. https://doi. org/10.1080/08958370701432108.

162. Sung JH, Ji JH, Song KS, Lee JH, Choi KH, Lee SH et al. Acute inhalation toxicity of silver nanoparticles. 
Toxicol Ind Health 2011 Mar;27(2):149-54. https://doi. org/10.1177/0748233710382540.

163. Dong MS, Choi JY, Sung JH, Kim JS, Song KS, Ryu HR et al. Gene expression profiling of kidneys from SpragueDawley rats following 12-week inhalation exposure to silver nanoparticles. Toxicol Mech Methods 2013 Jul;23(6):43748. https://doi.org/10.3109/15376516.2013.780196.

164. Lee HY, Choi YJ, Jung EJ, Yin HQ, Kwon JT, Kim JE et al. Genomics-based screening of differentially expressed genes in the brains of mice exposed to silver nanoparticles via inhalation. J Nanopart Res 2010;12:1567-78. https://doi. org/10.1007/s11051-009-9666-2.

165. Glass DC, Mazhar M, Xiang S, Dean P, Simpson P, Priestly $\mathrm{B}$ et al. Immunological effects among workers who handle engineered nanoparticles. Occup Environ Med 2017 Dec;74(12):868-76. https://doi.org/10.1136/ oemed-2016-104111.

166. Erdely A, Hulderman T, Salmen R, Liston A, ZeidlerErdely PC, Schwegler-Berry D et al. Cross-talk between lung and systemic circulation during carbon nanotube respiratory exposure. Potential biomarkers. Nano Lett 2009 Jan;9(1):36-43. https://doi.org/10.1021/n1801828z.
167. Aragon M, Erdely A, Bishop L, Salmen R, Weaver J, Liu $\mathrm{J}$ et al. MMP-q-dependent serum-borne bioactivity caused by multiwalled carbon nanotube exposure induces vascular dysfunction via the CD36 Scavenger receptor. Toxicol Sci 2016 Apr;150(2):488-98. https://doi.org/10.1093/toxsci/ kfw015.

168. Marczylo EL, Jacobs MN, Gant TW. Environmentally induced epigenetic toxicity: potential public health concerns. Crit Rev Toxicol 2016 Sep;46(8):676-700. https:// doi.org/10.1080/10408444.2016.1175417.

169. Dusinska M, Tulinska J, El Yamani N, Kuricova M, Liskova A, Rollerova E et al. Immunotoxicity, genotoxicity and epigenetic toxicity of nanomaterials: new strategies for toxicity testing? Food Chem Toxicol 2017 Nov;109(Pt 1):797-811. https://doi.org/10.1016/j.fct.2017.08.030.

170. Debia M, Bakhiyi B, Ostiguy C, Verbeek JH, Brouwer DH, Murashov V. A systematic review of reported exposure to engineered nanomaterials. Ann Occup Hyg 201660 (8): 916-935. https://doi.org/10.1093/annhyg/mew041.

Received for publication: 27 August 2018 